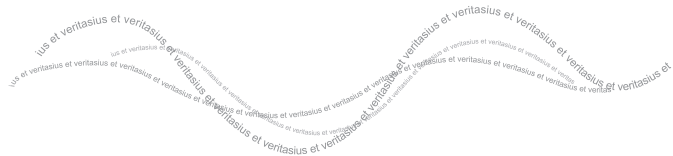

\title{
Nulidad de actos administrativos contrarios a las sentencias en el Texto Único Ordenado de la Ley peruana del Proceso Contencioso-Administrativo(*)
}

\author{
Nullity of administrative acts contrary to the judgments in the "Texto Único \\ Ordenado" of the Contentious-Administrative Process Law
}

\author{
Manuel Rebollo Puig ${ }^{(*)}$ \\ Universidad de Córdoba (Córdoba, España)
}

\begin{abstract}
Resumen: El artículo 48 del Texto Único Ordenado de la Ley que regula el Proceso Contencioso-Administrativo (aprobado mediante el Decreto Supremo 011-2019JUS) establece como causa de nulidad de actos y reglamentos su contradicción con sentencias dictadas con el fin de eludir su cumplimiento. Se analizan en el trabajo todos los elementos y requisitos para que concurra esa causa de nulidad. Y se sostiene que tal causa de nulidad se puede alegar y estimar en trámite de ejecución de sentencia y en procesos autónomos.
\end{abstract}

Palabras clave: Jurisdicción Contencioso-Administrativa - Ejecución de sentencias nulidad de actuaciones administrativas - Derecho Administrativo

\begin{abstract}
The article 48 from the called "Texto Único Ordenado" of the ContentiousAdministrative Process Law establishes as a cause of nullity of acts and regulations its contradiction with judgments, in order to avoid its compliance. All the elements and requirements, so that this cause of nullity might happen, are analyzed in the paper. And it is argued that such cause of nullity can be successfully alleged in the process of enforcement of judgments and in autonomous processes.
\end{abstract}

Keywords: Contentious-Administrative Jurisdiction - Enforcement of judgments - Nullity of administrative decisions - Administrative Law

$\left(^{*}\right) \quad$ Nota del Editor: este artículo fue recibido el 17 de marzo de 2020 y su publicación fue aprobada el 13 de mayo de 2020.

${ }^{* *}$ Catedrático de Derecho Administrativo en la Universidad de Córdova. Miembro del Grupo de investigación de la Junta de Andalucía SEJ-196. Proyecto de Investigación del Ministerio de Economía y Competitividad PGC2018-093760-B-I00. 


\section{Planteamiento}

El artículo 48 del Texto Único Ordenado de la Ley que regula el Proceso Contencioso-Administrativo, Ley 27584, aprobado mediante Decreto Supremo 011-2019-JUS (en lo sucesivo, abreviadamente, LPCA), bajo el rubro "Actos administrativos contrarios a la sentencia", dispone:

"Son nulos de pleno derecho los actos y disposiciones contrarios a los pronunciamientos de las sentencias que se dicten con la finalidad de eludir el cumplimiento de éstas".

Muchos son los interrogantes que este lacónico precepto suscita: ¿qué tipo de actuaciones administrativas pueden incurrir en tal causa de nulidad?; ¿qué requisitos han de concurrir para que surja esta concreta causal de nulidad?; ¿qué cauces hay para alegar esta nulidad? Contestar a estas preguntas es el objetivo de este trabajo.

Abordaré este objetivo sirviéndome de las respuestas que ante cuestiones idénticas y con una normativa similar se han dado en el Derecho español. En efecto, el precepto transcrito es prácticamente igual al artículo 103.4 de la española Ley 29/1998 Reguladora de la Jurisdicción Contencioso-Administrativa (en adelante LJCA) a cuyo tenor:

"Serán nulos de pleno derecho los actos y disposiciones contrarios a los pronunciamientos de las sentencias, que se dicten con la finalidad de eludir su cumplimiento".

Ante esta práctica identidad, parece asumible que las soluciones que han ido acuñando la jurisprudencia y la doctrina españolas puedan arrojar alguna luz para la interpretación del artículo 48 LPCA.

Con todo, conviene prevenir contra traslaciones precipitadas de las soluciones de un ordenamiento al otro. Aunque el artículo 48 de la peruana LPCA es casi igual al artículo 103.4 de la española LJCA, el contexto no es igual. Al menos, deben destacarse dos diferencias.

En primer lugar, debe apuntarse el distinto alcance de la nulidad de pleno derecho en el Perú y en España. En España, se supone que la nulidad de pleno derecho de los actos administrativos es la excepción dentro de la categoría general de la invalidez. Sólo una serie limitada de vicios son causas de nulidad de pleno derecho (artículo 47.1 de la Ley 39/2015 de Procedimiento Administrativo Común). Cualquier otra infracción del ordenamiento jurídico en que incurran sólo determina su anulabilidad (artículo 48 de la misma Ley 39/2015). Así que el hecho de que el artículo 103.4 LJCA opte por considerar que los actos a los que se refiere son precisamente nulos de pleno derecho tienen un valor en tanto que comporta elegir el grado máximo de invalidez con las consecuencias que ello arrastra (no demasiadas, pero sí algunas como la posibilidad de revisión de oficio en todo momento). Por el contrario, en el Derecho Administrativo peruano la Ley del Procedimiento
Administrativo General (Decreto Supremo 004-2019-JUS que aprueba el Texto Único Ordenado de la Ley 27444) establece como regla general la nulidad de pleno derecho para los actos administrativos viciados. Así se desprende de su artículo 10 que parece, incluso, no dejar espacio alguno para la anulabilidad. Sólo para las disposiciones reglamentarias viciadas que, en España, según jurisprudencia y doctrina mayoritarias, son siempre nulas, los dos ordenamientos se aproximarían. Prescindiendo de esto último, se puede afirmar que cuando el artículo 103.4 de la española LJCA proclama la nulidad de los actos que contrarían sentencias está reforzando la gravedad del vicio y se sus consecuencias de entre el conjunto de los que pueden aquejar a los actos administrativos; mientras que el artículo 48 de la peruana LPCA, al proclamar esa misma nulidad de pleno derecho de los actos contrarios a las sentencias, no hace sino reflejar la regla general aplicable a cualquier vicio.

La segunda diferencia podría ser, al menos en principio, más relevante. $Y$ es que el transcrito precepto español se completa en el siguiente párrafo con otro precepto procesal que no tiene parangón en la LPCA. Pero esta diferencia merece ya un tratamiento más detenido.

\section{La nulidad prevista en el artículo 48 de la ley del proceso contencioso- administrativo y la implícita admisión de su declaración en ejecución de sentencia}

En la LJCA española, tras proclamar la causa de nulidad en los términos ya vistos, el apartado siguiente, esto es el apartado 5 del mismo artículo 103, dispone:

\footnotetext{
"El órgano jurisdiccional a quien corresponda la ejecución de la sentencia declarará, a instancia de parte, la nulidad de los actos y disposiciones a que se refiere el apartado anterior, por los trámites previstos en los apartados 2 y 3 del artículo 109, salvo que careciese de competencia para ello conforme a lo dispuesto en esta Ley".
} 
O sea, que la nulidad por contrariar sentencias puede ser instada y declarada en el proceso de ejecución de sentencias; esto es, que el interesado no se verá obligado a acudir a un nuevo proceso contencioso-administrativo ordinario para impugnar ese acto y conseguir la declaración judicial de nulidad, sino que tiene expedita una vía más directa, rápida y ágil para lograr esa nulidad. Pero la Ley peruana no ha incluido nada similar ¿Cómo debe entenderse esa omisión? Para responder con seguridad y autoridad es necesario conocer el Derecho peruano con una amplitud y profundidad que no está a mi alcance. Pero, incluso así, osaré afirmar que lo más razonable es entender que también en el Perú esa declaración de nulidad puede conseguirse en ejecución de sentencia, es decir, que el Derecho peruano no obliga a los beneficiarios de una sentencia a acudir y sustanciar desde el principio a un nuevo contenciosoadministrativo para conseguir que se declare la nulidad de un acto o de un reglamento que vulnera aquélla. Dos géneros de razones me llevan a entenderlo así.

No cabe invocar el artículo 103.5 de la española LJCA como argumento para sostener que en Perú la solución debe ser la misma. Incluso en sentido opuesto podría afirmarse que, si el legislador peruano asumió la regla de la nulidad, pero no hizo lo mismo con la del cauce procesal para alcanzar su declaración es porque no quiso acoger éste. Pero acaso sí tenga más valor el origen de esos dos apartados 4 y 5 de la LJCA. En la anterior ley española de la jurisdicción contencioso-administrativa no había ninguna regla semejante a las actuales que hemos recordado. $Y$, sin embargo, todavía bajo la vigencia de aquella ley de 1956, pero con la inspiración de la Constitución Española de 1978, el Tribunal Constitucional conformó una jurisprudencia que prácticamente adelantó la posibilidad de instar la nulidad de las actuaciones administrativa contrarias a sentencias en la ejecución de las sentencias. Ello hasta el punto de que puede decirse que el artículo 103.4 y 5 LJCA no hizo nada más que plasmar en preceptos legales lo que ya consagraba, como directamente derivado de la Constitución, la jurisprudencia del Tribunal Constitucional español (en adelante, TC) ${ }^{(1)}$. De esa jurisprudencia traigamos aquí sólo un botón de muestra, la STC 167/1987, de 28 de octubre, que fue especialmente célebre y que, además, nos servirá luego para comprender otros aspectos de la regulación que nos ocupa. Un funcionario recurrió la resolución de unos concursos de traslado de los que había sido excluido (al parecer había sido declarado "no idóneo" para cualquier destino en el exterior mediante una especie de sanción encubierta e ilegal). La sentencia anuló los actos impugnados y reconoció al recurrente el derecho a optar a los puestos de trabajo de que se trataba. En ejercicio del derecho reconocido, el funcionario recurrente optó por la Jefatura de la Oficina Nacional Española de Turismo en San Francisco (EEUU). Y, en efecto, la Administración, aunque con cierto retraso, le otorgó dicha Jefatura. Pero poco después la Administración decidió reorganizar sus servicios en el exterior, cerrar la referida Oficina en San Francisco (fue sustituida por un Comisionado de Turismo para el oeste y sur de los Estados Unidos con sede en Los Ángeles) y adscribir al recurrente a los servicios en Madrid del Instituto para la Promoción del Turismo. El afectado acudió al Tribunal que había dictado la sentencia estimatoria para que anulara en trámites de ejecución esos actos. Pero el Tribunal desestimó tal pretensión por entender que la sentencia ya había quedado cumplida con el nombramiento del recurrente como Jefe de la Oficina de San Francisco; si ahora quería combatir actos posteriores, eso, dijo ese Tribunal, tendría que ser objeto de un nuevo proceso contencioso-administrativo. Ante ello el funcionario frustrado acudió en amparo ante el TC alegando que había sido vulnerado su derecho a la tutela judicial efectiva que incluye el derecho a la ejecución de las sentencias pues sólo hubo "una ejecución aparente y un desamparo real y auténtico". Pues bien, el TC otorgó el amparo. Es decir, consideró que la respuesta del Tribunal ordinario de remitir la decisión sobre la validez o invalidez de los nuevos actos a otro proceso contencioso-administrativo declarativo vulneraba el derecho a la tutela judicial efectiva en su faceta de derecho a la ejecución de las sentencias. Se lee en ella:

(1) Así Huerta Garicano, I. (2000) La ejecución de sentencias en la Ley 29/1998, de la Jurisdicción contencioso-Administrativa. Cuadernos de Derecho Judicial, 2, p. 107, afirma que lo que hacen los apartados 4 y 5 del artículo 103 LJCA es sólo "recoger de forma expresa una realidad jurisprudencial". Véase también Font i Llovet, T. (1993). Medidas para hacer efectiva la ejecución de las sentencias. En L. Martín-Retortillo Baquer (coord.), La protección jurídica del ciudadano. Estudios en homenaje al Profesor Jesús González Pérez (p. 181). Madrid: Civitas. No sólo lo aceptaba la jurisprudencia constitucional sino también la ordinaria. Baste la cita de la STS de 10 de mayo de 2001 (casación 8495/1998; Ar. 3706) que, aunque posterior a la LJCA de 1998, todavía no la aplica: "Los Tribunales contencioso-administrativos pueden adoptar en fase de ejecución cualquier medida que sea exigida para la ejecución del fallo (...) entre ellas, desde luego, la anulación de actos administrativos dictados para la ejecución o pretendida ejecución del fallo (STC 153/1992, de 19 de octubre)". 
“(...) el derecho a la ejecución de las Sentencias y demás resoluciones firmes de los órganos judiciales no se satisface sólo, como es patente, con la remoción inicial de los obstáculos que a su efectivo cumplimiento pueda oponer la Administración, sino que postula, además, que los propios órganos judiciales reaccionen frente a ulteriores actuaciones o comportamientos enervantes del contenido material de sus decisiones, y que lo hagan, esto es lo esencial, en el propio procedimiento incidental de ejecución (...) Sólo así se garantiza la eficacia real de las resoluciones judiciales firmes y, por ende, del control jurisdiccional sobre la Administración, y sólo así pueden obtener cumplida satisfacción los derechos de quienes han vencido en juicio, sin obligarles a asumir la carga de nuevos procesos, que resultaría incompatible con la tutela eficaz y no dilatoria que deben prestar los órganos judiciales".

Lo que ahora importa enfatizar es que dice que "lo esencial" es que eso se haga "en el propio procedimiento incidental de ejecución" y que no se obligue a "asumir la carga de nuevos procesos". En suma, se entendió que, aun sin ningún precepto legal que lo previera, el derecho a la tutela judicial efectiva exigía que los actos dictados en contra de la efectividad de la sentencia pudieran ser anulados justamente por los trámites de ejecución de esa sentencia. A la misma línea respondió el Tribunal Supremo de España (en lo sucesivo, TS). Si se acepta que esta jurisprudencia es correcta y que incluso es su misma doctrina la que subyace en el artículo 48 LPCA, parece que este precepto peruano debe entenderse en el sentido de que, además de consagrar una específica causa de nulidad, quiere establecer, aunque no lo diga expresamente, que ese vicio de nulidad puede hacerse efectivo en incidente de ejecución de la sentencia vulnerada.

Por otra parte, el artículo 44 LPCA permite perfectamente afirmar que la voluntad del legislador peruano fue concentrar por completo en el Juzgado o Tribunal de la ejecución (que a su vez es el mismo que conoció del proceso declarativo) y en el mismo proceso ejecutivo todos los conflictos que se susciten en torno a la efectividad de la sentencia y, entre ellos, el que suscitan los actos y disposiciones a que se refiere el artículo 48 de la misma Ley. Es decir, que lo más razonable es entender que si la ley peruana no consagró explícita y formalmente que la nulidad por contrariar sentencias se tiene que declarar por el Juez de la ejecución y en el proceso de ejecución es porque consideró que la regla general del artículo 44 era suficiente para justificar esa solución. Además, así cobra más sentido la inclusión en esa parte de la LPCA dedicada a la ejecución de la regla de su artículo 48: si, como hemos visto, la proclamación de la nulidad de pleno derecho de los actos y disposiciones contrarios a las sentencias es casi superflua en el Derecho peruano (dada la amplitud con la que prevé la nulidad el artículo 10 de la Ley del Procedimiento Administrativo General), el precepto se hace verdaderamente significativo si se interpreta que lo que implícitamente establece es que esa causal de nulidad puede invocarse con éxito en los incidentes de ejecución sin tener que iniciar un nuevo proceso contenciosoadministrativo declarativo.

En resumen, creo que puede y debe mantenerse que la LPCA establece dos reglas: la que formalmente contiene su artículo 48 sobre la nulidad de pleno derecho de los actos y disposiciones contrarios a las sentencias y la implícita de la posible declaración de tal nulidad en la ejecución de la sentencia vulnerada. Por tanto, si antes decía que la inexistencia en el Perú de un precepto similar al español artículo 103.5 LJCA podría marcar una diferencia importante, ahora, conforme a la interpretación de la LPCA que propongo, afirmo que es una diferencia más bien irrelevante y que, en el fondo, los dos Derechos establecen la misma solución.

Más todavía: la posibilidad de invocar exitosamente la nulidad por vulnerar sentencias en incidente de ejecución es más amplia en el Derecho peruano que en el español. Es así porque el artículo 103.5 LJCA establece un límite que no existe en el Derecho peruano. Obsérvese que el artículo 103.5 LJCA señala finalmente una excepción: "...salvo que careciese de competencia para ello conforme a lo dispuesto en esta Ley". Es una limitación severa: el juez de la ejecución sólo podrá anular el acto o disposición contrario a la sentencia en trámite de ejecución si ese juez también hubiera sido el competente para conocer de un recurso contencioso-administrativo autónomo contra ese acto $^{(2)}$. Si no se da esa coincidencia de

(2) Esta limitación legal ha sido criticada por la doctrina. Así, por todos, Morillo-Velarde Pérez, J. I. (1999). La ejecución de sentencias en el proceso contencioso administrativo. Revista del Poder Judicial, 55, p. 329-330; y Santamaría Pastor, J. A. (2010). La Ley Reguladora de la Jurisdicción Contencioso-Administrativa. Madrid: Iustel, p. 1095. Cosa distinta, es que esta limitación legal no impida que el juez de ejecución ante el que se alegue un nuevo acto o reglamento como causa de imposibilidad legal de ejecución de la sentencia, pueda denegarla basándose en la nulidad del artículo 103.4 LJCA. Vid. Baño León, J. M. (1998). Artículo 103.4 y 5. REDA, 100, p. 723-725; y Huergo Lora, A. (2001). La permanencia de un viejo problema: la reiteración de los actos administrativos anulados como forma de incumplimiento indirecto de las sentencias, con especial referencia a los efectos de los recursos de casación 
competencia (esto es, si el órgano judicial de la ejecución no es el competente para enjuiciar en abstracto la actuación con el vicio del artículo 103.4) no es que pueda promoverse ante otro órgano judicial este incidente; es que queda cegado por completo este cauce del artículo 103.5 LJCA ${ }^{(3)}$. Pues bien, este límite no existe en el Derecho peruano. Del artículo 44 LPCA se infiere que todo lo concerniente a la ejecución de sentencias (y la aplicación de la causa de nulidad del artículo 48 de la misma Ley lo es) compete al Juzgado o Sala que "conoció del proceso en primera instancia" (párrafo primero) y debe resolverlo "en el propio proceso de ejecución” (párrafo segundo). Ello sin excepción alguna. Consecuentemente, insisto, no sólo es que en el Perú los actos y disposiciones contrarios a las sentencias puedan ser declarados nulos por el órgano judicial encargado de la ejecución y en el incidente de ejecución, sino que eso es posible en todo caso sin la notable restricción que sí impone la LJCA en el inciso final de su artículo 103.5.

Conviene aclarar que el hecho de que la causal de nulidad del artículo 48 LPCA pueda invocarse y declararse en ejecución de sentencia no significa que ése sea el único cauce para hacer valer tal vicio invalidante. Lo que sobre todo importa destacar es que con frecuencia, aunque no siempre, podrá encauzarse en un proceso contencioso-administrativo autónomo en el que, además, podrán alegarse cualesquiera otros vicios del acto o disposición impugnados.
Si se opta por invocar la nulidad del artículo 48 LPCA en ejecución de sentencia, no cabrá invocar en esa sede otros vicios. Los demás vicios en que incurra el mismo acto o reglamento no tienen cabida en este incidente y habrá que esgrimirlos por otros cauces $^{(4)}$. Por eso, la resolución judicial que se dicte en ejecución desestimando la pretensión anulatoria basada en los artículos 48 LPCA o 103.4 LJCA no impedirá que prospere la pretensión anulatoria fundada en otros vicios y ejercida por otros cauces ${ }^{(5)}$; esto es, que no tendrá efecto de cosa juzgada material o, más exactamente, sólo lo tendrá respecto de la causa de nulidad de los artículos 48 LPCA o 103.4 LJCA, no para el resto de vicios que se imputen a la misma actuación administrativa.

Por lo demás, el Derecho peruano ofrece una respuesta a una cuestión que no resuelve la española LJCA. Dice in fine el artículo 44 LPCA que "antes de acudir al Juez encargado de la ejecución, el interesado, si lo considera conveniente, podrá solicitar en vía administrativa la reconsideración de la actuación que originó la actuación". Esa

en interés de Ley, RAP, 156, p. 303-305. Y la jurisprudencia lo acepta como demuestra, por todas, la STS 113/2019, de 4 de febrero (casación 3965/2017; Ar. 354): "(...) la falta de competencia para declarar la nulidad de pleno derecho de tales actos o disposiciones no desapodera al órgano jurisdiccional para ejercer el correspondiente control en la ejecución de la sentencia, que tiene atribuido por ley, y en tal sentido valorar si los actos y disposiciones que se invocan como justificación para alegar el incumplimiento de la sentencia en sus propios términos, incurren en la causa de nulidad establecida, que en caso afirmativo determina la total ineficacia de los mismos a los efectos pretendidos en ejecución y, en consecuencia, el correspondiente pronunciamiento judicial desestimando la alegación de imposibilidad formulada al amparo del artículo 105.2 LJCA".

(3) En ese sentido, Clavero Arévalo, M. (2003). Actuaciones administrativas contrarias a los pronunciamientos de las sentencias. En M. Montoro Chiner (coord.), La justicia administrativa. Libro homenaje al Prof. Dr. D. Rafael Entrena Cuesta. Barcelona: Atelier, p. 929.

(4) Así, dice la STS de 8 de noviembre de 2012 (casación 4561/2011; Ar. 10656): en el cauce del artículo 103.5 LJCA "no nos corresponde pronunciarnos (...) sobre cualquier vicio de ilegalidad que pueda contener dicha modificación del plan general, que ahora no pueden ser considerados. Todo ello sin perjuicio de la interposición de un recurso contencioso-administrativo independiente y autónomo sobre tal modificación en la que pueda esgrimirse cualquier infracción del ordenamiento jurídico". Por eso afirma la STS de 6 de abril de 2011 (casación 1602/2007; Ar. 2962) que la vía del recurso contencioso-administrativo autónomo ante el órgano jurisdiccional competente será "la vía a seguir en el supuesto de que, junto a esta particular acción de tintes subjetivos (la del artículo 103.4), se articulara otra basada en la nulidad material del nuevo acto o planeamiento". Lo mismo en la STS de 29 de septiembre de 2009 (casación 2827/2005; Ar. 325 de 2010); y la STS 1997/2016, de 6 de septiembre (casación 3365/2014; Ar. 5776) insiste con profusión de argumentos en la exclusión del incidente del artículo 103.5 LJCA de cualquier vicio distinto. Véase Calvo Rojas, E. (2012). Los planes urbanísticos como disposiciones de carácter general. Problemas que suscita la declaración de nulidad de los instrumentos de planeamiento. Suspensión cautelar de la efectividad de los planes impugnados en vía jurisdiccional". En E. García Enterría. y R. Alonso García (coord.), Administración y justicia. Un análisis jurisprudencial: liber amicorum Tomás-Ramón Fernández (Vol. 1, p. 830). Madrid: Civitas.

(5) Lo aclara expresamente alguna sentencia. Por ejemplo, la STS de 28 de diciembre de 2006 (casación 384/2004, Ar. 4582 de 2007), tras desestimar la nulidad del artículo 103.4 en incidente del artículo 103.5 LJCA, dice: "Con ello no estamos diciendo que tal actuación resulte correcta -pues ello no es objeto de este incidente- pero sí que (...) al adoptar los nuevos acuerdos el Ayuntamiento (...) no está realizando actividad alguna (...) con la finalidad de contravenir los pronunciamientos del fallo". Igualmente, la STS de 27 de mayo de 2008 (casación 2648/2006; Ar. 3494): desestima la acción de nulidad basada en el artículo 103.4 y 5 LJCA contra unas normas forales; pero aclara en su fundamento $5^{\circ}$ que ello no afecta a lo que haya de resolverse en el recurso autónomo contra las mismas normas que habían interpuesto otras entidades pues "(...) la cuestión de fondo planteada sigue viva y pendiente de resolución $(\ldots)$ ". 
solicitud de reconsideración habrá de encauzarse, entiendo, por los cauces del recurso administrativo que en cada caso proceda según los artículos 218 y siguientes de la Ley de Procedimiento Administrativo General y preceptos complementarios. Pero queda claro en la parte reproducida del artículo 44 LPCA que tales recursos son en todo caso meramente potestativos y que, si el interesado lo prefiere, puede acudir al Juez de la ejecución prescindiendo por completo de plantear su pretensión en vía administrativa.

Expuestos, aunque sucintamente, los aspectos formales o procedimentales, analicemos con más detenimiento los sustantivos, esto es, la amplitud y alcance de la causal de nulidad que nos incumbe. Lo haremos prestando destaca atención a las sentencias de la Sala de lo ContenciosoAdministrativo del Tribunal Supremo español sobre los apartados 4 y 5 del artículo 103 LJCA que son ya numerosas y ofrecen una doctrina sólida(6) que, mutatis mutandis, puede ser también útil para el Perú.

\section{Actuaciones que pueden estar incursas en la causa de nulidad del artículo 48 LPCA}

\author{
3.1. Cualesquiera actuaciones jurídicas de la \\ Administración; no actuaciones materiales \\ El precepto se refiere a "los actos y disposiciones". Naturalmente \\ actos y disposiciones distintos de los ya anulados por la sentencia.
}

Aunque el artículo 48 LPCA no lo especifique, han de provenir de la Administración. Quedan, pues, extramuros de ese artículo 48 las leyes, incluso cuando contengan decisiones singulares de convalidación o cualesquiera otras que impidan la ejecución de sentencias ${ }^{(7)}$. Y quedan dentro los actos administrativos y los reglamentos. A estos últimos hay que entender que se refiere el artículo 48 cuando habla de "disposiciones". Aunque no expresamente nombrados, deben considerarse comprendidos igualmente los convenios y contratos suscritos por la Administración: lo contrario dejaría al margen de esta causa de nulidad un frente de posibles incumplimientos sin ningún fundamento sólido. En suma, todos los tipos de actuaciones jurídicas de la Administración pueden incurrir en esta causa nulidad. Por el contrario, quizá quepa excluir a las actuaciones materiales y las simples omisiones. Así se entiende en España ${ }^{(8)}$. Pero es que en el Derecho español esa exclusión se refuerza con el artículo 108.2 LJCA que prevé otra vía para combatir las omisiones y actuaciones materiales contrarias a las sentencias ${ }^{(9)}$. Al no existir en la LPCA un precepto semejante cabría plantear si no hay que dar a su artículo 48 mayor amplitud para

(6) Se ha dicho que los tribunales españoles son poco proclives a aplicar esta causa de nulidad en ejecución de sentencias. Así, Fernández Rodríguez, T. R. (2011). El artículo 130.4 LJCA no les gusta a los jueces. En Sánchez Blanco, A., Domínguez Berrueta de Juan, M. A., y Rivero Ysern, J. L. (coord.), El nuevo Derecho Administrativo. Libro homenaje al Profesor Dr. Enrique Rivero Ysern (p. 139-146). Salamanca: Ratio Legis y Universidad de Salamanca.; y Fernández Torres, J. R. (2018). La ejecución de sentencias sigue siendo un auténtico quebradero de cabeza veinte años después de la aprobación de la LJCA. RAAP, 100, p. 175, que censura "la resistencia de los Jueces y Tribunales a enjuiciar en sede de ejecución, con fundamento en lo dispuesto en el artículo 103.4 LJCA, los actos y disposiciones dictados por la Administración (...) y su preferencia (...) por proponer a los ejecutantes la interposición de un nuevo recurso...". Acaso sea así en los Juzgados y Tribunales inferiores. Sea como fuere, no es eso lo que se desprende de la jurisprudencia del TS de los últimos años en la que, incluso, más bien puede detectarse la tendencia contraria.

(7) Galán Galán, A. (2006). Los poderes del juez en la ejecución de las sentencias: reacción frente a actos de la Administración o del legislador que tengan como fin eludir su cumplimiento. En A. Sánchez Lamelas (coord.), La ejecución de las sentencias contenciosoadministrativas (p. 136-137). Madrid: Aranzadi Thomson Reuters. También las leyes, por supuesto, pueden contradecir sentencias con la finalidad de impedir su cumplimiento y eventualmente puede que ello acarree su nulidad por vulneración del derecho a la tutela judicial efectiva. Así lo ha declarado el TC español en muchas sentencias como las 312/2006 y 50/2015. Y lo mismo vale para el Derecho peruano. Pero eso tiene otro régimen no el de los artículos 103 LJCA y 48 LPCA.

(8) No obstante, los primeros comentaristas de la LJCA mantuvieron lo contrario. Así, Gimeno Sendra, V. (1999). Comentarios a la nueva Ley de la Jurisdicción Contencioso-Administrativa (p.73). Madrid: Centro de Estudios Ramón Areces; y Clavero (2003, p. 928). Hoy es una posición descartada por la jurisprudencia y la mayoría de los autores.

(9) Dice ese artículo 108.2 LJCA: "Si la Administración realizare alguna actividad que contraviniera los pronunciamientos del fallo, el Juez o Tribunal, a instancia de los interesados, procederá a reponer la situación al estado exigido por el fallo (...)”. La STS de 31 de enero de 2006 (casación 8263/2003; Ar. 4356) refleja esta doctrina: “(...) pueden deducirse dos supuestos diferentes de ejecución fraudulenta, el primero (103.4 y 5 LJCA), con una connotación estrictamente jurídica, y, el segundo (108.2 LJCA), que pudiera tener como fundamento una actuación de tipo material: 1) Para evitar, justamente, este tipo de actuaciones, el artículo 103 en sus números 4 y 5 , contempla la situación, dibujada por el legislador, de los supuestos "de los actos y disposiciones contrarios a los pronunciamientos de las sentencias, que se dicten con la finalidad de eludir su cumplimiento" (...) 2) El segundo supuesto (108.2 LJCA) (...) viene determinado no como consecuencia de una actividad jurídica de la Administración -esto es mediante actos o disposiciones dictados para contradecir los pronunciamientos de las sentencias, que acabamos de examinar- sino como consecuencia de una actividad 
dar cabida en él a las omisiones o meras actuaciones materiales de la Administración contrarias al fallo. Pese a ello, considero que no tiene sentido predicar la nulidad nada más que de las actuaciones jurídicas ${ }^{(10)}$ y que, sin perjuicio de que el Juzgado o Tribunal de la ejecución tenga poderes para proscribir las meras omisiones o actuaciones materiales contrarias a lo fallado (que se deducen genéricamente de los arts. 44 y 45 LPCA), la nulidad del artículo 48 sólo debe predicarse de las actuaciones jurídicas de la Administración. Ahora bien, si la actuación material combatida tiene sustento en algún acto de la Administración, entonces sí será pertinente combatir este conforme al artículo 48 LPCA $^{(11)}$.

\subsection{Actuaciones administrativas en cumplimiento de la sentencia y actuaciones en ejercicio de cualesquiera potestades}

Las actuaciones jurídicas de la Administración que pueden incurrir en esta causa de nulidad son de dos géneros. Por un lado, las que se produzcan formal y directamente para cumplir el fallo. Aquí entran los actos de la Administración debidos para el cumplimiento de la sentencia (aunque precisamente se les impute que más bien la contradicen); es decir, los producidos para la equívocamente Ilamada "ejecución voluntaria de la sentencia". Así, por ejemplo, si la sentencia declara el derecho de una persona a ser nombrada funcionaria $y$, por ende, condena a la Administración demandada a reconocerlo, el acto de nombramiento que dicte entra en esta categoría. Son actos de la Administración que, según se suele explicar, no son propiamente actos administrativos sino que tienen otra naturaleza ${ }^{(12)}$.

Por otro lado también están incluidos los reglamentos, actos y convenios administrativos producidos al margen del cumplimiento de la sentencia en ejercicio ordinario de las potestades de la Administración: si la sentencia declaró nulo un reglamento, la aprobación de otro reglamento no será cumplimiento de aquella sentencia, sino simple ejercicio de la potestad reglamentaria que la Administración tiene completamente al margen de la sentencia anulatoria anterior, pero también podrá ser nulo en virtud del artículo 48 LPCA $^{(13)}$; lo mismo si la sentencia, por ejemplo, anuló

material de la propia Administración "que contraviniere los pronunciamientos del fallo" de la misma. Es, como decimos, el supuesto contemplado en el artículo 108.2 LJCA (...)”. Igualmente, entre otras, SSTS de 26 de diciembre de 2006 (casación 385/2004, Ar. 4582 de 2007), 10 de mayo de 2007 (casación 3786/2004, Ar. 8062), 12 de diciembre de 2014 (casación 2847/2012; Ar. 6823), 1280/2017 de 18 julio (casación núm. 1264/2016; Ar. 3967) y 1646/2017, de 31 de octubre (casación 1677/2016; Ar. 4812).

(10) Así, Xiol Ríos, J. A. (2016). Artículo 103. En E. Espín Templado (coord.), Comentarios a la Ley Reguladora de la Jurisdicción Contencioso-Administrativa (p. 723). Valencia: Tirant lo Blanch.

(11) Véase Xiol Ríos, J. A. (2016, p. 723).

(12) La doctrina ha insistido en ello. Así, Font i Llovent, T. (1985). La ejecución de las sentencias contencioso-administrativas. Aspectos constitucionales. Madrid: Civitas, y, Font i Llovent, T. (2003). Justicia administrativa y ejecución de sentencias. En Montoro Chiner, M. J. (coord.), La justicia administrativa. Libro homenaje al Prof. Dr. D. Rafael Entrena Cuesta (p. 822-826). Barcelona: Atelier, donde afirma que "ejecutar o cumplir una sentencia ya no es administrar". Sobre todo Baño León, J. (2016). La eficacia de las sentencias contra la Administración o la claudicación del Estado de Derecho, REDA, 177, p. 87, 92 y 96, ha recalcado que en estos supuestos de actuación de la Administración condenada por sentencia no hay "un acto administrativo dictado al amparo de una competencia específica"; "(...) no es (...) un acto administrativo en sentido propio (...)"; "(...) el acto de la Administración dictado para materializar la sentencia no es un acto administrativo emanado de la simple voluntad de la Administración (...)". Y antes ya Tornos Mas, J. (1998). Artículo 103.1, 2 y 3, REDA, 100, p. 717, explicaba que "en esta ejecución no actúa como Administración, ejerciendo potestades propias y actuando objetivamente al servicio de intereses generales, sino que actuará como parte vencida en juicio (...) La posición de la Administración ha cambiado de modo sustancial (...)". Más radicalmente se pronuncia respecto a las actuaciones de la Administración como mera colaboradora en la ejecución de sentencias correspondientes a procesos en los que no ha sido parte (p. 719). Pero no es esto último lo que ahora nos incumbe. También Ortega Álvarez, L. (2001). La ejecución de sentencias. En Leguina Villa, J. y Sánchez Morón, M. (direct.), Comentario a la Ley de la Jurisdicción Contencioso-Administrativa (2da ed., p. 504-505). Valladolid: Lex Nova, apunta esas ideas. En igual dirección Huerta Garicano (2000, p. 106), dice: “(...) los actos dictados por la Administración en ejecución de sentencias firmes no son actos de ésta sujetos a Derecho Administrativo y susceptibles de impugnación autónoma en vía jurisdiccional, sino que son diligencias de ejecución de lo resuelto en sentencia que se revisan (...) dentro del mismo proceso (...)".

(13) Exactamente igual debe decirse ante las anulaciones judiciales de planes de urbanismo ante lo que la aprobación de uno nuevo no es ejecución de la sentencia anulatoria. Alguna vez lo ha explicitado el TS: "Ciertamente, anulado un plan urbanístico, la Administración puede abandonar todo propósito ulterior de acometer la ordenación pretendida. Forzoso resulta admitir la renuncia como una opción..." (sentencia de 5 de julio de 2012, casación 2922/2010; Ar. 7735). No se trata propiamente de una renuncia, pero la afirmación sirve para patentizar que, como regla general, salvo que de la concreta sentencia se deduzca otra cosa, la Administración puede perfectamente dejar en vigor el plan resurgido sin emprender ahora su revisión. Como dice Baño León, J. M. (2012). La retroacción de actuaciones ¿denegación de justicia o garantía del justiciable?. En E. García Enterría y R. Alonso García (coord.), Administración y justicia. Un análisis jurisprudencial. Liber amicorum Tomás-Ramón Fernández (Vol. 1, p. 598). Madrid: 
una concesión: el otorgamiento de una nueva concesión, que no imponía aquella sentencia, no será cumplimiento de la sentencia, pero sí que puede reunir los requisitos de esta causa de nulidad del artículo 48 LPCA. Justamente el que este otro tipo de actuaciones puedan incurrir en esta causa de nulidad y declararse en ejecución de sentencie fue la novedad más relevante de la $\mathrm{LJCA}^{(14)}$. Y lo mismo puede decirse del artículo 48 LPCA.

Ambos géneros de actuaciones pueden ser nulas en virtud del artículo 48 LPCA. Pero, incluso así, la distinción es crucial pues tienen en parte régimen procesal diferente. Antes dije que con frecuencia esta causa de nulidad puede canalizarse en un proceso contencioso-administrativo autónomo. Con frecuencia, pero no siempre. Al menos, en España el TS distingue: si se trata de impugnar actos de la Administración dictados en ejercicio de sus potestades ordinarias por la nulidad del artículo 103.4 LJCA cabe hacerlo en ejecución de sentencia, pero también en recurso contencioso-administrativo autónomo está abierto(15); por el contrario, cuando se trata de impugnar esas actuaciones administrativas producidas directamente para cumplir una sentencia sólo es posible hacerlo en incidente de ejecución de la misma sentencia. Lo contrario comportaría sacar de la ejecución lo que es propio y exclusivo de ella y en ocasiones privar al juez de la ejecución de su competencia en favor de otro juez. Además, supondría dar trato de genuinos actos administrativos a los que, según tesis mayoritaria, estrictamente no lo son(16). En principio, entiendo que lo

Civitas, "en procedimientos normativos y de planificación", tras la anulación por sentencia del reglamento o plan, "retomar o no el procedimiento entra en la discrecionalidad de la Administración"; por tanto, si decide retomarlo, eso no es ejecución de la sentencia.

(14) Lo explica Xiol Ríos (2016, p. 721): “(..) la relevancia de este precepto radica en que se refiere no sólo a los actos que la Administración dicte directamente para ejecutar la sentencia -sobre los cuales no existía ya duda (...) de que podían ser anulados durante el procedimiento de ejecución si no se ajustaban al fallo- sino también de los actos (...) que, ajenos en principio al proceso de ejecución, obstaculizan la efectividad de la sentencia (...)". Antes había detectado que esto era "lo realmente novedoso", Galán Galán (2006, p. 138).

(15) Es representativa la STS de 20 de marzo de 2014 (casación 4333/2011; Ar. 2414). Frente a la alegación de que el artículo 103.4 no podía invocarse en un recurso autónomo sino sólo en la vía incidental de ejecución prevista en el artículo 103.5 LJCA, dice: “(...) sin perjuicio de que en efecto pudo dicha cuestión haberse hecho valer por la vía indicada, tampoco nuestra Ley impide entablar un recurso contencioso-administrativo autónomo y la consiguiente formación de un nuevo litigio, por lo que no impone la vía antes señalada de los artículos 103 y siguientes de manera necesaria". En idéntico sentido, entre otras, SSTS de 5 de febrero de 2008 (casación 2027/2006; Ar. 458); 29 de septiembre de 2009 (casación 2827/2005; Ar. 325 de 2010); 18 de noviembre de 2011 (casación 5883/2008; Ar. 2297 de 2012); 8 de febrero de 2013 (casación 2134/2012; Ar. 1382); 19 de febrero de 2013 (casación 5525/2010; Ar. 3195); 892/2016, de 25 de abril (casación 290/2015; Ar. 1858); y 2481/2016, de 21 de noviembre (casación 3207/2015; Ar. 6582). Por sólo transcribir un pasaje de alguna, se lee en la de 18 de noviembre de 2011: “... no es cierto que la existencia de una anterior sentencia anulatoria de un Plan General excluya de manera absoluta la posibilidad de que el nuevo plan aprobado sea objeto de impugnación en un proceso autónomo. Ciertamente, la nulidad del nuevo Plan podrá pedirse como incidente de ejecución de la anterior sentencia, al amparo de lo previsto en los apartados 4 y 5 del artículo 103 LJCA; pero también en un proceso autónomo, siendo esto último lo procedente cuando se aducen otras causas de nulidad además de la referida al intento de eludir la anterior sentencia".

(16) Éste es el fundamento teórico y último de esta regla que sólo permite en el enjuiciamiento judicial de estos actos en ejecución de sentencia. Lo ha explicado Baño León (2016, p. 87, 92 y 96). Dice: "(...) esos actos no deben ser objeto de impugnación autónoma, sino en todo caso objeto de examen en el incidente de ejecución" y "por el juez de la ejecución". La STS de 15 de enero de 1999 (casación 30/1995; Ar. 349; nótese, sentencia incluso anterior a la actual LJCA) era ya explícita: "(...) el auto de inadmisión razona que (el acto municipal) no resulta impugnable, por tratarse de una mera ejecución de lo ordenado en una sentencia firme, sin que quepa un recurso contencioso-administrativo nuevo sobre una materia juzgada (...). Este razonamiento concuerda plenamente con la doctrina expresada por esta Sala en reiteradas ocasiones. Sin entrar en el debate de cuál sea su auténtico carácter -administrativo, procesal o de naturaleza jurídica intermedia entre lo administrativo y lo procesal- es claro que los actos dictados en el proceso de ejecución de una sentencia firme deben ser combatidos en el trámite incidental correspondiente del proceso en que se dictó la sentencia que mediante ellos se ejecuta, deduciendo las peticiones adecuadas ante el órgano jurisdiccional que conoce y resuelve de la ejecución. No resulta admisible por ello la interposición de recursos contencioso-administrativos sucesivos frente a tales actos (...)". Cita otras sentencias anteriores a la LJCA de 1998 Tolosa Tribiño, C. (2006). El incidente de ejecución de sentencias: aspectos procesales. En Sánchez Lamelas, A. (coord.), La ejecución de sentencias contencioso-administrativas (p. 178-179). Madrid: Aranzadi Thomson Reuters. Y Fernández Hernando, J. (1961). El incumplimiento de la sentencia administrativa, sus formas y su tratamiento jurisprudencial. En Libro homenaje al profesor Jordana de Pozas (Vol. I, Tomo III, p. 248-253). Madrid: Instituto de Estudios Políticos, y Fernández, T. R., (1974). Algunas reflexiones sobre las formas indirectas de incumplimiento por la Administración de las sentencias de los tribunales de la jurisdicción contencioso-administrativa, RAP, 73, p. 161, se remontan a las SSTS de 17 de mayo de 1943 , 9 de noviembre de 1944 y 20 de noviembre de 1949. Véase también la STS de 10 de noviembre de 2006 (casación 4020/2003; Ar. 10074). Por sólo citar una STS más reciente, es ilustrativa la 90/2018, de 25 de enero (casación 3/2017; Ar. 254): una vez que el tribunal había determinado exactamente lo que un Ayuntamiento debía hacer para cumplir una sentencia, inadmite un recurso autónomo para discutir lo que ese Ayuntamiento había hecho para esa ejecución: “... el acuerdo dictado por el Ayuntamiento (...) 
mismo hay que afirmar en Perú. Si es así, partiendo de que, conforme a lo antes razonado, también aquí cabe declarar la nulidad en los trámites de ejecución de sentencia, hay que añadir ahora algo más: que si se trata de actos dictados formalmente como de cumplimiento de la sentencia no es sólo que se pueda, sino que su impugnación debe hacerse precisamente en ejecución de sentencia. Pese a todo, no existiendo un precepto como el del artículo 103.5 LJCA, quizá sea una conclusión excesiva considerar que en esos casos los recursos contencioso-administrativos autónomos contra ese género de actos y basados en la nulidad del artículo 48 LPCA deban ser inadmitidos.

\subsection{Actuaciones administrativas posteriores e incluso anteriores a la sentencia}

Cabría pensar en principio que esta causa de nulidad sólo puede aquejar a actuaciones jurídicas posteriores a la sentencia. Pero en España, aunque el TS acogió inicialmente esa tesis ${ }^{(17)}$, después, en la línea preconizada por algún autor ${ }^{(18)}$, terminó por aceptar que esta causa de nulidad también puede afectar a actos y reglamentos anteriores a la sentencia. Ello cuando, vaticinando una sentencia adversa, se dictaron preventivamente con la finalidad de eludirla. Lo explica la STS de 19 de junio de 2013 (casación 2713/2012):

"No es correcto el criterio (según el cual) el artículo 103.4 LJCA está previsto [únicamente] para los supuestos de que, previa existencia de un pronunciamiento jurisdiccional, se dicten con posterioridad actuaciones o disposiciones que inciden de forma directa en la ejecución de la previa sentencia. No obstante ser esa situación la más frecuente, puede ocurrir igualmente que, vaticinando el resultado adverso del proceso todavía no resuelto, se realicen actuaciones precisamente con el designio fraudulento de evitar el cumplimiento"(19).

Pese a las complicaciones que esto introduce, la misma conclusión resulta acertada para el Derecho peruano: no sólo es que el artículo 48 LPCA no excluya a los actos y disposiciones anteriores a la sentencia, sino que su exclusión dejaría un flanco abierto muy peligroso. En estos casos, la nulidad del artículo 48 LPCA no podrá invocarse hasta que se produzca (y alcance firmeza, como luego se explicará) la sentencia que pretende contradecirse y eludirse; pero los efectos de la nulidad se retrotraerán al momento mismo en que se dictó el acto o reglamento nulo ex artículo 48 LPCA $^{(20)}$.

\section{Resoluciones judiciales cuya vulneración puede comportar la nulidad del artículo 48 LPCA}

\author{
4.1. Sentencias y autos contencioso- \\ administrativos \\ No dice el artículo 48 LPCA (como no lo \\ dice el artículo 103.4 LJCA) que la sentencia
}

en ejecución de sentencia debió haber sido impugnado por la recurrente en el seno del incidente de ejecución de sentencia por cuanto (...) lo que ha hecho es cumplir su deber legal de ejecutar la sentencia, no estando permitida una impugnación autónoma (...)".

(17) SSTS de 3 de marzo de 1999 (casación 323/1994), de 29 de octubre de 2001 (casación 2543/1996), ATS de 5 de febrero de 2001. No obstante, pueden detectarse algunas desviaciones; por ejemplo, en STS de 19 de mayo de 1999 (Ar. 3639). Vid. González Pérez, J. (1998). Comentarios a la Ley de la Ley de la Jurisdicción Contencioso-Administrativa (3ra ed., Tomo II, p. 1785). Madrid: Civitas, y Clavero Arévalo (2003, p. 928).

(18) Ortega Álvarez, L. (2001, p. 509): “... dada la literalidad del artículo 103.4, si existe prueba de que (...) se dictaron en previsión de una sentencia desfavorable (...) cabría la declaración de nulidad por el trámite de incidentes dado el sentido teleológico del precepto". Véase también Ezquerra Huerva, A. (2014). La ejecución de sentencias. En A. Ezquerra Huerva y J. Oliván del Cacho. (direct.), Estudio de la Ley de la Jurisdicción Contencioso-Administrativa (p. 975-976). Valencia: Tirant lo Blanch; Galán Galán (2006, p. 139); Agoués Mendizábal, C. (2017). La modulación de los efectos de la invalidez de los reglamentos. En El alcance de la invalidez de la actuación administrativa: Actas del XII Congreso de la Asociación Española de Profesores de Derecho Administrativo (p. 401). Madrid: INAP; Suay Rincón, J. (2018). La "afectación" de la anulación de los Planes de Urbanismo a sus actos de ejecución: la perspectiva de la Ley Jurisdiccional, Revista de Derecho Urbanístico y Medio Ambiente, 324, p. 45.

(19) Buen ejemplo es la STS de 19 de febrero de 2013 (casación 5525/2010; Ar. 3195): anuló un plan de urbanismo que salvaba una edificación cuya licencia se veía en peligro aunque se aprobó antes de la sentencia anulatoria de tal licencia; ello porque la Administración era "perfectamente conocedora de la pendencia de ese proceso judicial" y con la aprobación del plan buscaba "sólo anticiparse a una inminente declaración judicial de nulidad" y así "frustrar una sentencia estimatoria con la que ya contaba de antemano": pretendía "anticipar la respuesta a una declaración de nulidad que vislumbraba ineludible". En la misma dirección, véanse, entre otras, SSTS de 18 de diciembre de 2014 (casación 2847/2012; Ar. 6823), de 12 de marzo de 2015 (casación 1881/2014; Ar. 3626), STS 1285/2016 de 2 junio (Ar. 3123) y 1997/2016, de 6 de septiembre (casación 3365/2014; Ar. 5776).

(20) Por eso no puede decirse exactamente que estemos en un supuesto de invalidez sobrevenida. Sigo en este punto a Cano Campos, T. (2004). La invalidez sobrevenida de los actos administrativos. Madrid: Civitas, p. 224-229, que acoge un concepto restrictivo. Explica que no basta para que haya invalidez sobrevenida que el vicio surja después del acto, sino que es necesario que también los efectos de la invalidez sean posteriores al acto y no se retrotraigan al momento originario en que se dictó; es decir, que para que haya invalidez sobrevenida tiene que tratarse de un supuesto en que se acepte que el acto ha producido durante cierto tiempo 
vulnerada haya ser del orden contencioso-administrativo. Pero, al incluirse en la LPCA, la conclusión se impone: quedan fuera las resoluciones de cualquier otra jurisdicción o del TC. Dentro del orden contencioso-administrativo, pese a que el precepto en cuestión habla precisamente de sentencias, igual causa de nulidad concurrirá cuando la actuación jurídica de la Administración contradiga autos de esa jurisdicción; por ejemplo, los que adopten medidas cautelares ${ }^{(21)} \mathrm{o}$, rizando el rizo, los que resuelvan incidentes de ejecución.

\subsection{Sentencias de condena; pero también merodeclarativas ¿incluso desestimatorias?}

Desde luego, esta causa de nulidad procede ante la vulneración de sentencias de condena a la Administración. Pero no sólo ante ellas: puede tratarse de sentencias meramente declarativas (las que declaran una nulidad de pleno derecho) o constitutivas (las que anulan lo anulable). El artículo 48 LPCA (como el artículo 103.4 LJCA) no se refiere exclusivamente a sentencias de condena y, en realidad, tampoco de su función y sentido general cabe deducir tal limitación. Es más, en gran parte de los casos en los que se ha aplicado el artículo 103.4 LJCA la sentencia de partida era meramente declarativa o constitutiva, no de condena. Es cierto que ante ese género de sentencias nada concreto y positivo debe hacer o dar la Administración para su cumplimiento. Pero sí hay que acatarlas, no actuar en contra de sus pronunciamientos. $Y$ es este deber negativo el que aquí encuentra respaldo. Más todavía y hasta más sorprendente: aunque las sentencias desestimatorias (que, por tanto, confirman el acto recurrido) no deben ser objeto de ejecución judicial(22), acaso sí que podrían fundamentar la nulidad que estudiamos $^{(23)}$; en concreto, tal vez podría imputarse esta nulidad del artículo 48 LPCA a una resolución administrativa que anulase el acto confirmado por sentencia(24).

efectos lícitos que no se van a destruir. Y esto no se daría en el caso aquí analizado pues el acto o reglamento dictado antes de la sentencia, pero vaticinando su resultado adverso y tratando de eludirlo tendrá una nulidad cuyos efectos se retrotraerán al momento en que se dictaron. Estaremos, pues, ante una nulidad originaria, aunque con la singularidad de que no podrá invocarse desde el primer momento sino sólo cuando se dicte la sentencia que se quería burlar. Acaso pueda decirse que hay una ilegalidad sobrevenida pero no propiamente una invalidez sobrevenida.

(21) Ya apuntó Fernández, T. R. (1974). Algunas reflexiones sobre las formas indirectas de incumplimiento por la Administración de las sentencias de los tribunales de la jurisdicción contencioso-administrativa, $R A P, 73$, p. 175-177, que los mismos problemas que surgen ante los actos que reproducen al anulado por sentencia se dan respecto a los actos que reiteran al suspendido por auto; y no hay razón para que la respuesta sea distinta. Véase la sentencia del Tribunal de Conflictos de Jurisdicción de 17 de junio de 2008; Ar. 1973 de 2010) que precisamente versaba sobre la aplicación del artículo 103.4 LJCA ante un acto administrativo contrario al auto de medidas cautelares.

(22) Lo que en tales casos procede ejecutar es el acto administrativo confirmado, no la sentencia confirmatoria; y naturalmente aquello se hace siguiendo las reglas del procedimiento administrativo, no las procesales. Véase González Pérez (1998, p. 996-997); Huerta Garicano (2000, p. 104); y Tolosa Tribiño (2006, p. 175-177).

(23) Al menos, así lo entendió la STS de 23 de diciembre de 2010 (casación 2970/2006; Ar. 1033 de 2011). Lo que hizo la sentencia de cuya supuesta ejecución se trataba fue desestimar el recurso y, por tanto, confirmar un acto administrativo por el que se ordenaba demoler una construcción. Luego el Ayuntamiento revisó el plan de urbanismo con lo que aquella obra se convertía en legal y devenía imposible ejecutar la decisión administrativa de demolición. Pero el TS aceptó aplicar frente a esa revisión del plan urbanístico el artículo 103.4 LJCA. Creo que se equivocó. Lo que protegió no fue propiamente hablando lo decidido por una sentencia sino lo decidido por la Administración, aunque confirmado por sentencia; aquí poco tenía que ver el derecho a la tutela judicial efectiva.

(24) El TS, con distintos argumentos (la cosa juzgada; o la literalidad el artículo 102.1 Ley 30/1992, como ahora el artículo 106.1 de la Ley del Procedimiento Administrativo Común, que se refieren a actos "que no hayan sido recurridos en plazo") niega la posibilidad de revisión de oficio del acto judicialmente confirmado (SSTS de 28 de enero de 2014, casación 553/2012, Ar. 683; de 13 de febrero de 2015, casación 537/2013, Ar. 1052; y de 25 de noviembre de 2015, casación 269/2014, Ar. 5411). Con todo, en algún supuesto excepcional se ha admitido la revisión de oficio de actos confirmados en sentencia (así en la STS 57/2017, de 18 de enero, que reiteradamente insiste en que se basa en las características singulares del caso; casación 1469/2015; Ar. 1198). Véanse Bueno Armijo, A. (2016). La revisión de oficio. En H. Gosálbez Pequeño (direct.), La nueva Ley del Procedimiento Administrativo Común (p. 449). Madrid: Wolters Kluwer; Suay Rincón, J. (2014). La caracterización jurídica de la potestad de revisión de oficio. En J. SorianoGarcía (direct.), Por el Derecho y la libertad. Libro homenaje al Profesor Juan Alfonso Santamaría Pastor (Tomo II, p. 1385). Madrid: lustel; y Rebollo Puig, M. (1998). Artículos 72 y 73, REDA, 100, p. 525. Según creo, la revisión de oficio del acto confirmado debe quedar proscrita sólo cuando se oponga a lo ya juzgado y, por tanto, sería lícita si se basara en vicios distintos de los analizados en la sentencia o si se tratara de sentencia sin cosa juzgada (como las desestimatorias de recursos directos contra reglamentos). Dejando estos aspectos al margen, lo que apuntamos en el texto es que, suponiendo que en un determinado caso realmente la revisión de oficio vaya contra lo ya juzgado en la sentencia confirmatoria, tal revisión podría estar incursa en la causa de nulidad de artículo 48 LPCA. Y si esto se acepta es que, en efecto, también las sentencias desestimatorias sustentan esta causa de nulidad y hasta la posibilidad de declararla en ejecución de la sentencia. Es esto lo que obiter dicta admiten las SSTS de 20 de octubre de 2008 (casación 5719/2006; Ar. 5750) y de 24 de mayo de 2011 (casación 3338/2010; Ar. 4687). Dicen que no cabe afirmar "de forma categórica (...) que las sentencias desestimatorias no son ejecutables": "el alcance eminentemente declarativo del pronunciamiento desestimatorio del recurso no impide que puedan suscitarse incidentes de ejecución. Piénsese, por ejemplo, que la Administración 


\subsection{Sentencias firmes}

Dije antes que la nulidad del artículo 48 LPCA puede aquejar a actos anteriores a la sentencia. Si es así, con mayor razón pueden incurrir en esa nulidad los actos posteriores a la sentencia, pero anteriores a su firmeza. Ahora bien, sólo desde el momento en que la sentencia pretendidamente contradicha y eludida devenga firme cabrá invocar con éxito esta causa de nulidad $^{(25)}$. Ni siquiera la ejecución provisional de la sentencia determinará por sí misma esta nulidad. Aceptar lo contrario, teniendo en cuenta que la sentencia vulnerada puede ser revocada, sería tanto como admitir una nulidad que primero aparece y luego desaparece. Y consecuentemente llevaría a entender que la resolución judicial que anulara un acto de acuerdo con el artículo 48 LPCA podría perder después su eficacia cuando la sentencia vulnerada fuese revocada. Nada de eso es asumible.

\section{Los dos requisitos de la vulneración de sentencias necesarios para que se dé la nulidad del artículo 48 de la Ley del Proceso Contencioso-Administrativo}

El artículo 48 LPCA proclama la nulidad de los actos y disposiciones "contrarios a los pronunciamientos de la sentencia, que se dicten con la finalidad de eludir su cumplimiento". Ello en idénticos términos a los del artículo 103.4 LJCA. De ambos preceptos se deduce por igual que son necesarios dos requisitos: uno objetivo, la contradicción material con la sentencia; y otro subjetivo, la finalidad de eludir su cumplimiento. Así lo expone la jurisprudencia española que pormenoriza el significado de cada uno de ellos. Expongamos esa jurisprudencia que, con mínimas matizaciones, podría ser válida para interpretar y aplicar el artículo 48 LPCA.

5.1. El requisito objetivo: contradicción con los pronunciamientos de la sentencia La contradicción con "los pronunciamientos de la sentencia" ha de ser con su fallo ${ }^{(26)}$. Ahora bien, más allá de las palabras pronunciadas en el fallo, inexorablemente hay que atender también a la ratio decidendi de la sentencia. Sin ella no se puede saber siquiera lo que realmente se ha fallado. Pero no se trata de dar valor autónomo a la ratio decidendi(27) pues ello sería tanto como incluir en el artículo 103.4 LJCA (o en el peruano artículo 48 LPCA) la vulneración de la doctrina de los tribunales, lo que daría una amplitud absurda a esta causa de nulidad y llevaría a la ejecución de las sentencias asuntos ajenos a lo juzgado(28). Lo que hay que proclamar es que se da este requisito objetivo cuando hay contradicción con el fallo, pero acotado éste en función de la ratio decidendi.

La ratio decidendi incluye la motivación jurídica fundamental(29) y los hechos determinantes tomados en consideración,

vencedora en el litigio inicia luego los trámites para la revocación de ese mismo acto, o para su revisión de oficio, o sencillamente, desiste de ejecutar la decisión cuya validez ha sido respaldada en vía jurisdiccional; y es entonces un tercero (...) quien insta ante el Tribunal el efectivo cumplimiento de lo decidido en la sentencia (...)".

(25) En contra Clavero Arévalo, M., (2003, p. 932), no exigía que la sentencia fuese firme.

(26) Clavero Arévalo, M. (2003, p. 931). Si admitimos, como aquí se ha hecho, que también puede haber esta nulidad por vulnerar autos, la contradicción deberá referirse a su "resuelve".

(27) Galán Galán, A. (2006, p. 140-141): “(...) la declaración de nulidad del artículo 103.4 LJCA se extiende no sólo a los actos y disposiciones que sean contrarios al fallo, sino también a los fundamentos jurídicos, siempre que constituyan ratio decidendi de la sentencia". Más exacto es decir que se extiende solo al fallo, aunque éste haya de interpretarse atendiendo a la ratio decidendi.

(28) Es importante destacarlo y excluir del artículo 103.4 LJCA (y del artículo 48 LPCA) ciertos casos en los que la contradicción con la ratio decidendi es flagrante y hasta sangrante. Piénsese en una sentencia que, por ejemplo, anule una una sanción por entender que determinada conducta no es típica. Si después la Administración vuelve a sancionar una conducta igual, incluso contra el mismo sujeto, estará actuando ilegalmente. Entre otras cosas porque conforme a la ratio decidendi de la sentencia anterior ya debe aceptarse que tal género de conducta no es típica. Acaso incluso pueda decirse que la autoridad que imponga esa nueva sanción estará prevaricando. De acuerdo. Todo lo que se diga sobre la ilegalidad de esa nueva sanción será poco. Pero, aceptado eso, lo que no cabe decir es que esa nueva sanción impuesta por otros hechos (aunque iguales a los anteriores) incurre en la contradicción con la sentencia anterior de que habla el artículo 103.4 LJCA: no es contraria a lo fallado (aunque sí que sea contrario a la ratio decidendi). La idea queda bien reflejada en la STS de 20 de octubre de 2011 (casación 522/2009; Ar. 1317 de 2012). Distingue entre actuaciones contrarias al fallo y aquellas otras que no son contrarias al fallo sino sólo a la fundamentación de la sentencia. En este segundo caso no procede ninguna modalidad de ejecución sino a lo sumo interponer un nuevo recurso invocando esa fundamentación: "(...) independientemente de que la fundamentación conducente a ese fallo, que no el fallo mismo, pudiera servir de base $(\ldots)$ a pretensiones similares $(\ldots)$ para formular recursos diferenciados $(\ldots)$ ".

(29) No, por supuesto, a lo que solo aparezca como obiter dicta. A este respecto es rotunda la STS 127/2019, de 6 de febrero (Ar. 410): acepta que se tenga en cuenta la ratio decidendi de la sentencia de casación, pero no los razonamientos obiter dicta "sin influencia alguna en el fallo". 
para cuyo acotamiento ocasionalmente hay que atender a la totalidad del debate procesal, empezando por la demanda y su causa petendi(30).

Por lo que concierne a la motivación jurídica, si de una sentencia anulatoria se trata habrá que atender al concreto vicio que ha llevado a la anulación judicial. De modo que, incluso aunque el nuevo acto o reglamento fuese de contenido material igual al anulado, no se dará el requisito objetivo -y, por tanto, no será de aplicación el artículo 103.4 LJCA (o el peruano artículo 48 LPCA)- si no se incurre en el mismo vicio que determinó su anulación. Así, si los vicios por los que se anuló un acto o reglamento fuesen formales nada obstará a que, tras la tramitación pertinente, lo decidido en el nuevo acto, reglamento sea igual a lo establecido en el anulado por sentencia ${ }^{(31)}$; si la nulidad se hubiera decretado por falta o insuficiencia de motivación, no será ilícito volver a aprobar el mismo acto, reglamento ahora con una motivación adecuada(32); si la nulidad se hubiera acordado por vulneración de una norma superior, nada impedirá la modificación de esa norma superior y la aprobación posterior de un reglamento igual al antes anulado, tras todo el procedimiento exigido( ${ }^{(3)}$; etc. Hasta cabe afirmar que en estos casos, lejos de contradicción con la sentencia, se cumple escrupulosamente ${ }^{(34)}$.

Y en lo que atañe a los hechos relevantes para la sentencia su cambio sustancial puede impedir que el nuevo acto o reglamento caiga en el artículo 103.4 LJCA (o en el artículo 48 LPCA) por falta del requisito objetivo incluso aunque sea de contenido igual al del anulado por la sentencia(35). Así, por ejemplo, la

(30) Encuentra ello apoyo en la jurisprudencia constitucional. Por ejemplo, explica la STC 50/2015, de 5 de marzo: "(...) fallo, fundamentos de las partes, hechos debatidos y argumentos planteados en defensa de las posturas encontradas son manifestaciones de "una línea secuencial que une las alegaciones y pretensiones de la parte actora, con la fundamentación jurídica y argumentación que funda la Sentencia, para desembocar en el fallo y concretos pronunciamientos en ésta contenidos. La función jurisdiccional de decir el Derecho, presupuesto necesario de la ejecución, no permite una consideración aislada de cada uno de dichos momentos y actos procesales, sino que requiere su valoración unitaria y global, pues ésta es la que permite extraer, con mayor grado de certeza, el genuino alcance y significación de las determinaciones del órgano jurisdiccional y de los efectos jurídicos, de naturaleza formal o material, que deben producir aquéllas" (entre otras, SSTC 240/1998, de 15 de diciembre, FJ 3; 83/2001, de 26 de marzo, FJ 4; 146/2002, de 15 de junio, FJ 3, o STC 116/2003, de 16 de junio, FJ 3)". Si esto es así en general para determinar el alcance de la ejecución, también puede serlo para delimitar el ámbito de la contradicción con las sentencias de que habla el artículo 103.4 LJCA o, para lo que nos ocupa, del artículo 48 LPCA.

(31) Lo dice la STS de 19 junio 2013 (casación 2713/2012 Ar. 5629): "Aunque por sentencia pueden anularse las previsiones de los planes, el titular de la potestad de ordenación territorial o urbanística conserva todavía opciones que excluyen la aplicación automática de las normas anteriores, porque en el ejercicio de esas potestades pueden ser aprobados nuevos instrumentos, y con más razón cuando la causa determinante de la invalidez decretada por sentencia haya sido debida a defectos de tramitación del instrumento (...)". Vid. Agoués Mendizábal, C. (2017, p. 402-403).

(32) Así, no se ha encontrado inconveniente, por ejemplo, a que anulado el cese de un funcionario por falta de motivación, se considere bien ejecutada la sentencia dictando nueva resolución de cese ahora motivada, pese a que se le daban efectos retroactivos (STC 83/2001, de 26 de marzo); o a que, anulada la calificación urbanística de unos suelos por falta de motivación, un plan posterior la reiterase ahora con esa motivación, máxime cuando las circunstancias podían haber cambiado (STS 1997/2016 de 6 de septiembre; casación 3365/2014; Ar. 5776).

(33) Por eso la STS de 8 de noviembre de 2012 (casación 4561/2011; Ar. 10656) no vio obstáculo a que, anulado un plan especial porque el plan general preveía un estudio de detalle, se volviese a aprobar el plan especial tras haber modificado el plan general que ya sí establecía como posible esa figura de planeamiento: "Se hace ahora lo que debió hacerse entonces, a saber, proporcionar desde el planeamiento general la cobertura normativa suficiente para que el posterior desarrollo encuentre su perfecto acomodo en el plan general (...) Conviene reparar que cuando la nulidad declarada obedece a la elección del instrumento de planeamiento y a la falta de acomodo del plan especial respecto de lo dispuesto en el plan general, la modificación posterior de éste de superior rango para incorporar lo que establecía ese plan especial declarado nulo no puede ser calificado como un caso elusivo del cumplimiento de la sentencia (...) Por el contrario (...) es un ejercicio que se enmarca dentro de la discrecionalidad propia del planificador...”. Véase igualmente STS de 18 de diciembre de 2008 (casación 1214/2007; Ar. 7346): plan parcial que infringía el plan general en cuanto a superficie mínima de parcela; pero licitud de la posterior modificación del plan general para decir lo que antes decía el plan parcial.

(34) En relación a planes de urbanismo y con evocaciones kantianas, es ilustrativa la STS 1997/2016, de 6 de septiembre (casación 3365/2014; Ar. 5776): "No puede desprenderse de nuestra jurisprudencia, desde luego, la existencia de un imperativo categórico que venga a impedir, siempre y sin excepción, la reproducción de la ordenación anulada por virtud de una sentencia firme"; "Habrá que estar a la entidad y naturaleza del vicio determinante de la anulación" y, por tanto, a la "ratio decidendi de las resoluciones judiciales" anulatorias; "Al amparo de su potestad de planeamiento, la Administración puede ejercitar una opción diferente y llevar a efecto una ordenación distinta, pero también le es dable proponer una ordenación planteada en términos similares (y aun idénticos, añado) a la que había sido anulada".

(35) Esto lleva a acotar la permanencia en el tiempo del valor de los fallos y a evitar que se produzca una "congelación" de la situación. Es lo que, como explicó Ortega Álvarez, L. (1999). La ejecución de sentencias, Justicia Administrativa: Revista de Derecho Administrativo, número extra 1, p. 156-157, permite que la Administración ante nuevas circunstancias haga "una nueva valoración 
sentencia que anule la calificación de unos terrenos no obsta a que se realice lícitamente esa misma calificación si han cambiado las circunstancias ${ }^{(36)}$.

Suele considerarse arquetipo del acto o reglamento que cumple este requisito objetivo del artículo 103.4 LJCA el que reproduce al anulado. Pero, como acabamos de ver, no siempre que se dicte un acto o reglamento que resuelva en el mismo sentido del anulado se dará tal requisito objetivo: no se dará si no incurre en el mismo vicio que llevó a su anulación judicial o si han cambiado sustancialmente las circunstancias fácticas determinantes. Aun así, sí que pudiera caer en este vicio del artículo 103.4 LJCA si se pretende retrotraer los efectos del nuevo acto al momento en que se dictó el anulado: al menos, esa retroactividad sí podría considerarse contraria a la sentencia; no sería nulo el nuevo acto o reglamento pero sí su retroactividad $^{(37)}$. Y precisamente el que el nuevo acto no tenga efectos retroactivos demuestra que la nulidad pronunciada por la sentencia no es meramente platónica.
$Y$ en sentido contrario hay actos $y$ reglamentos de contenido material diferente al del acto o reglamento anulado que sí que cumplen este requisito objetivo ${ }^{(38)}$.

Así sucede, por lo pronto, cuando se aprueban reglamentos o actos que, aun sin reproducir al anulado, se basan en él o le dan algún tipo de efectos ${ }^{(39)}$; o se los dan a algunos de los producidos a su amparo antes de la anulación( ${ }^{(40)}$.

También es habitual considerar que cumplen este requisito objetivo los nuevos reglamentos que alteran el marco jurídico que tuvo en cuenta la sentencia como base para pronunciar su fallo y que convierten en lícito lo que la sentencia consideró ilícito(41). Cosa distinta es que puede que pese a ello

del interés general volviendo a incidir sobre la materia que fue anteriormente objeto del fallo judicial, sin que se interprete que con ello" se actúa en contra de la sentencia.

Es sugerente la STS de 29 de octubre de 2001 (casación 2543/1996; Ar. 454 de 2002). Antes se había anulado judicialmente un plan de ordenación del tráfico de Sevilla. El TS contesta que "la eficacia de la sentencia no opera cuando la situación jurídica por ella definida se ha modificado por hechos o actos legítimos posteriores que no pudieron ser contemplados por la decisión judicial"; y que "ha de tenerse en cuenta que la nulidad apreciada judicialmente fue por no haberse seguido, en su día, por el Ayuntamiento el procedimiento establecido para dictar la disposición general que suponía dicho Plan; pero, en manera alguna, se desapodera a la Administración, sino que, por el contrario, se reconoce explícitamente la potestad de la Corporación municipal para la ordenación del tráfico (...). Por consiguiente, cabe entender que las decisiones municipales sobre la circulación de determinadas calles del centro de Sevilla sean independientes del Plan anulado, y que fueron adoptadas en razón a circunstancias distintas, incluso, sobrevenidas (...) pues no se pueden congelar las previsiones circulatorias porque fuera anulado un determinado Plan de Ordenación circulatoria y de estacionamiento por razones procedimentales". Como se habrá observado, esta sentencia también juega con el vicio que propició la anulación judicial. Incluso en otros pasajes descarta que se diera el requisito subjetivo. Pero lo esencial es que habían cambiado las circunstancias y es eso lo que ahora interesa destacar.

(36) STS de 5 de julio de 2012 (casación 2922/2010; Ar. 7735): "El hecho de que una sentencia anule una determinada calificación urbanística por falta de motivación no impide que, de forma indefectible, la misma calificación puede volver a plantearse en el futuro al amparo de circunstancias y motivaciones distintas (...) En definitiva, siendo la esencia del ius variandi la adaptación del contenido del planeamiento a las exigencias, cambiantes, que en cada momento demanda el interés general, el hecho de que determinada calificación no esté justificada en un momento dado no impide que posteriormente sí puede estarlo si las circunstancias fueran distintas, pues lo contrario supondría una especie de petrificación de la potestad de planeamiento incompatible con la satisfacción del interés general y una lesión a la potestad reglamentaria (...)".

(37) STS de 30 de septiembre de 2003 (casación 8614/1999; Ar. 8221): “(...) debemos proclamar que la facultad de otorgar efectos retroactivos a un acto administrativo (...) no puede aplicarse al proceso judicial de ejecución utilizándola para enmendar las consecuencias naturales de una declaración judicial de nulidad del acto administrativo (...)".

(38) Se lee por ejemplo en la STS de 17 de septiembre de 2010 (Ar. 709 de 2011): "Es cierto que no concurre identidad entre los dos instrumentos de planeamiento -Plan Especial de 1999 y Plan Especial de 2004- pero tal coincidencia no es lo que se exige en el artículo 103.4 LJCA, que se limita imponer los requisitos (de que) la disposición general nueva sea contraria a lo resuelto en sentencia y que se haya dictado con la finalidad de eludir su cumplimiento".

(39) Por ejemplo, se dicta providencia de apremio para ejecutar el acto anulado o se aprueban nuevos planes de desarrollo del anulado o se otorga licencia en aplicación del plan anulado. Respeto a esto último dice la STS de 12 de febrero de 2008 (casación 5953/2005, Ar. 1885) que se puede pedir la nulidad de la licencia concedida en aplicación del plan anulado en ejecución de la sentencia que anuló el plan "de conformidad con lo establecido en el artículo 103.4 LJCA. Y no podría decirse que se estaría entonces decidiendo cosa no juzgada, ya que tal problema es propio de la ejecución".

(40) Eso también contradice materialmente la sentencia. Porque, dada la retroactividad de la nulidad, los actos dictados en aplicación del nulo también son, en general, nulos; aunque ello tiene excepciones como la consagrada en el artículo 73 LJCA. Sobre ella, Rebollo Puig, M. (2018). Efectos de las sentencias anulatorias de reglamentos. En especial, su retroactividad, RAAP, 100, p. 505-513.

(41) Son numerosas las sentencias que declaran la nulidad del artículo 103.4 LJCA en estos supuestos, sobre todo ante cambios en los planes urbanísticos. Entre ellas ofrece un ejemplo bien simple y claro la STS de 24 de abril de 2014 (casación 5639/2011; Ar. 
no entren en el artículo 103.4 LJCA por no cumplir el requisito subjetivo que precisamente cobra en esa hipótesis más sentido y relevancia para distinguirlo de los casos en que el cambio normativo es causa legal de imposibilidad de ejecutar sentencias conforme a lo establecido en el artículo 105.2 LJCA.

Pero los tres géneros enumerados (actos que reproducen al anulado con sus mismos vicios y en iguales circunstancias; actos que dan efectos al anulado; y reglamentos que cambian el marco normativo de la sentencia) no agotan los que pueden cumplir el requisito objetivo del artículo 103.4 LJCA o del equivalente 48 LPCA. Hay muchas formas de contradecir sentencias y no cabe encerrar en unos cuantos tipos todas las que pudieran subsumirse en esta causa de nulidad(42). Aun así, no cabe desorbitar el ámbito de esta causa de nulidad confundiendo las ejecuciones aparentes con las reales, aunque hagan que las sentencias estimatorias tengan menos efectos prácticos de los que en principio cabría pensar.

\subsection{El requisito subjetivo: la finalidad de eludir el cumplimiento de la sentencia}

El segundo requisito, aunque criticado por la doctrina ${ }^{(43)}$, ha sido destacado por la jurisprudencia que habla de un "componente subjetivo", de un "elemento teleológico o intencional", de un animus, y lo exige siempre.
Los tribunales consideran que esta finalidad de eludir la sentencia constituye una modalidad de desviación de poder. Dijo la STS de 31 de enero de 2006 (casación 8263/2003; Ar. 4356):

“(..) lo que (...) debe demostrarse es, justamente, la mencionada finalidad de inejecutar la sentencia con el nuevo y posterior acto o disposición, o, dicho de otro modo, la concurrencia de la desviación de poder en la nueva actuación administrativa, en relación con el pronunciamiento de la sentencia"(44)

Por esa asimilación a la desviación de poder el TS ha excluido del artículo 103.4 LJCA las actuaciones regladas ${ }^{(45)}$. Conforme a ello, el ámbito por antonomasia de esta causa de nulidad sería el de las actuaciones en ejercicio de potestades discrecionales: así, a los límites generales de toda discrecionalidad se sumaría otro adicional, el de no ejercerse con la finalidad de elusión de sentencias. $Y$ efectivamente de ese modo lo explican muchas veces los tribunales ${ }^{(46)}$

2456): anulada una licencia para un comercio en local bajo rasante porque lo prohibía el plan, se modifica éste para permitir ese uso e imposibilitar la ejecución de la licencia.

(42) Como decía González Pérez, J. (2016). Comentarios a la Ley de la Ley de la Jurisdicción Contencioso-Administrativa (8va ed.). Madrid: Civitas, "los procedimientos utilizados por la Administración para lograr la inejecución de los fallos son infinitos. En todos los países los administradores muestran una habilidad extraordinaria para conseguir sus fines y lograr que prevalezca su criterio. Se ha llegado a decir que la Administración, a la que, por otra parte, se le reprocha su falta de imaginación, hace gala en este aspecto de una ingeniosidad notable" (p. 968). Siendo pues infinitos los artificios de que la Administración puede valerse para eludir las sentencias, no conviene encorsetar el artículo 103.4 en unos determinados tipos de actos.

(43) Así, Huergo Lora (2001, p. 296-298). También Clavero Arévalo (2003, p. 931) reprochó al artículo 103.4 la exigencia de este animus "pues debe bastar que la actuación sea contraria a los pronunciamientos para que se produzca la nulidad. Añadir el requisito de la desviación de poder supone introducir un factor de inseguridad innecesario (...). Por otra parte, con independencia de la gravedad de tal finalidad, lo fundamental es que la actuación sea contraria a los pronunciamientos de la sentencia, aunque no se haya dictado con la finalidad de eludir el cumplimiento (...)". Asimismo, Baño León (2016, p. 97-98 y 100), Xiol Ríos (2016, p. 722) y García Luengo, J. (2002). Los supuestos de nulidad de pleno derecho establecidos al margen de la Ley de Procedimiento Común, RAP, 159, p. 144

(44) La misma identificación con la desviación de poder luce, entre otras muchas, en las SSTS de 21 de junio de 2005 (casación 4936/2002; Ar. 8968), 28 de diciembre de 2006 (casaciones 384/2004, Ar. 4582 de 2007), 18 de diciembre de 2008 (casación 1214/2007, Ar. 7346), 6 de abril de 2011 (casación 1602/2007, Ar. 2962), 16 de diciembre de 2011 (casación 171/2008, Ar. 2830 de 2012), 19 de febrero de 2013 (casación 5525/2010; Ar. 3195), 18 de diciembre de 2014 (casación 2847/2012, Ar. 6823), 1774/2016 de 14 julio (casación núm. 3620/2015, Ar. 3799), 1955/2016, de 21 de julio (casación 3916/2015, Ar. 3916), 882/2017, de 22 de mayo (casación 2042/2016, Ar. 3491), 996/2017, de 5 de junio (casación 2271/2016, Ar. 3658) y 1280/2017, de 18 julio (casación 1264/2016, Ar. 3967).

También la doctrina asume la asimilación a la desviación de poder. Por todos Clavero Arévalo (2003, p. 929-931), Font i Llovet (2003, p. 824) y Suay Rincón (2018, p. 44).

(45) Por eso, por ejemplo, el TS ha descartado que pueda darse esta nulidad en el acuerdo de suspensión automática de licencias ante la aprobación inicial de planes en sustitución de otro anulado. Así, SSTS 1280/2017 de 18 julio (casación núm. 1264/2016; Ar. 3967) y 1646/2017, de 31 de octubre (casación 1677/2016; Ar. 4812). Ello pese a que, tras la anulación judicial de un plan con la consecuente reviviscencia del plan anterior, la suspensión de licencias puede convertir en una quimera esa reviviscencia y dar al traste con las expectativas de los demandantes que consiguieron la sentencia anulatoria de un plan que parece quedar burlada. Como al elaborar un nuevo plan sustitutorio del redivivo, la suspensión de licencias es reglada, no se incurriría en el vicio del artículo 103.4 LJCA. Con todo, según parte de la doctrina no hay nada que excluya a radice la desviación de poder en el ejercicio de potestades regladas.

(46) Muestra de ello, entre otras, es la STS de 28 de septiembre de 2009 (casación 2573/2005; Ar. 7345): “(...) aparte de los límites que acotan el ejercicio de la discrecionalidad administrativa en cualquier ámbito y de los diferentes cauces para su fiscalización 
Es de discutible acierto esa identificación de la finalidad de eludir la sentencia con una desviación de poder ${ }^{(47)}$. Y, aunque se acepte esa asimilación a la desviación de poder, como mínimo hay que añadir que es una desviación de poder con un régimen especial: no sólo por ser determinante de nulidad (no de anulabilidad, como es la regla general en España de acuerdo con el artículo 48.1 de la Ley de Procedimiento Administrativo Común) sino porque, en contra de la rigurosa exigencia de prueba que normalmente se requiere para estimar la existencia de tal desviación, aquí se presume iuris tantum cuando concurre el requisito objetivo ${ }^{(48)}$.

En efecto, no se carga al actor con la prueba de esa finalidad desviada, sino que recae sobre la Administración la demostración de que, pese a la contradicción con la sentencia, su finalidad no es eludirla. Lo sintetiza bien la STS de 29 de mayo de 2015 (casación 3301/2014; Ar. 3155):

"(...) hemos establecido, expresa o implícitamente, la inversión de la carga de la prueba, trasladando a la Administración el deber de probar que tales nuevos actos o disposiciones no persiguen como finalidad propia lograr la inejecución de la sentencia"

Son numerosas las SSTS que acogen esta inversión de la carga de la prueba ${ }^{(49)}$. E incluso en ocasiones parece que no se trata sólo de que cuando el nuevo acto o reglamento sea impugnado se demuestre en el proceso que su finalidad no es la eludir la sentencia sino

jurisdiccional (necesaria observancia del procedimiento, respeto a los hechos determinantes, control de los elementos reglados de la decisión, interdicción de la arbitrariedad, etc.), en el caso que nos ocupa es obligado destacar la concurrencia de un factor que necesariamente opera como un límite especialmente relevante a la discrecionalidad. Nos referimos, claro es, a la existencia de una resolución judicial firme (...) que, al haber declarado la nulidad de una licencia, la procedencia de demoler la edificación amparada en ella y el derecho de los demandantes en esos litigios a que tales pronunciamientos se ejecuten, configuran un estado de cosas que no puede ser ignorado". La idea estaba ya en la antes citada STC 167/1987, de 28 de octubre, en la que la vulneración de la sentencia anterior se había producido ejerciendo la discrecional potestad de autoorganización administrativa: se explicaba que ninguna sentencia puede eliminar "las facultades organizativas que ostenta la Administración Pública sus propios servicios" pero que "tales facultades de organización no pueden ser ejercidas en directo menoscabo o detrimento de la santidad de la cosa juzgada y con lesión del derecho (...) a la efectiva tutela judicial".

(47) No creo acertada esa identificación: puede que la Administración ejerza una potestad para lograr el interés general previsto en el ordenamiento y que, sin embargo, sí que tenga la finalidad de eludir la sentencia. Es más, a veces se trata de eludir el cumplimiento de una sentencia para conseguir que el resultado final sea adecuado a los intereses generales para cuya consecución esta atribuida la potestad ejercida: no habrá, pues, propiamente, desviación de poder. El requisito subjetivo del artículo 103.4 LJCA se mueve en un plano diferente a la desviación de poder. Se ve con claridad en los casos en que la Administración se sirve de la potestad de planeamiento urbanístico. A este respecto son sugerentes las explicaciones de Gómez-Ferrer Rincón, R. (2008). La imposibilidad de ejecución de sentencias en el proceso contencioso-administrativo. Madrid: Civitas, p. 321: "(...) puede ser (...) que la planificación urbanística se haya cambiado para hacer imposible la ejecución de la sentencia, pero (...) para proteger un determinado bien o valor constitucional, como puede ser el derecho a la vivienda o la protección de la riqueza"; "la fuerza normativa de dichos bienes o valores constitucionales" justifica que la Administración pueda ejercer su potestad de planeamiento para salvaguardarlos. Lo que hará la Administración al cambiar el plan en esa hipótesis será "en realidad (...) ajustar la normativa urbanística de acuerdo con el interés público urbanístico". Luego no habrá desviación de poder, aunque la jurisprudencia dominante subsuma tales supuestos en el artículo 103.4 LJCA. Cosa distinta es que los tribunales partan de que el interés público supremo es el de la ejecución de la sentencia -por estar conectado con un derecho fundamental y con la noción de Estado de Derecho- y que ante él todos los demás intereses públicos sucumban gracias al artículo 103.4 LJCA. Pero eso no significa que la Administración haya incurrido en desviación de poder. Por lo demás, negar la identificación entre el animus del artículo 103.4 LJCA y la desviación de poder salva mejor las críticas de Santamaría Pastor, J. A. (2014). Muerte y transfiguración de la desviación de poder: sobre las sentencias anulatorias de los planes, $R A P, 195$, p. 197 y ss., que subraya las diferencias de régimen entre la finalidad elusiva de la sentencia y la desviación de poder, diferencias a las que de inmediato nos referimos. En suma, la consideración de la finalidad elusiva del artículo 103.4 LJCA como una forma de desviación de poder ni es acertada desde el punto de vista conceptual ni desde el de las consecuencias de régimen jurídico: es una complicación sin fundamento que sólo genera confusión.

(48) O sea, según Chinchilla Peinado, J. A. (2008). La ejecución aparente del fallo de las sentencias contencioso-administrativas en el ámbito urbanístico. Un balance tras 10 años de vigencia de la Ley 29/1998, Revista de Derecho Urbanístico y Medioambiente, 245, p. 77 , se presume esta finalidad, o sea, se presume la desviación de poder, cada vez que el nuevo reglamento o acto impide la ejecución de la sentencia. Crítico con esta presunción en contra de la Administración se muestra Galán Galán (2006, p. 142-143); la defiende Ruiz Bursón, F. J. (2013), Las innovaciones en el planeamiento urbanístico como causa de imposibilidad legal para la ejecución de sentencias, RGDA, 33, p. 26-27.

(49) Sobre todo ante la aprobación de nuevos planes de urbanismo. Reseñemos sólo algunas notables.

- STS 1996/2016, de 6 de septiembre (casación 1215/2015; Ar. 4817): "Cuando se trata de valorar y determinar si la finalidad de la aprobación de un cambio de planeamiento tiene por finalidad eludir el cumplimiento de una sentencia judicial, se produce una inversión de la carga de la prueba, correspondiendo a la Administración autora de dicha modificación acreditar que la misma obedece a una finalidad general de mejora de la ordenación urbanística, ajena al incumplimiento de lo acordado por una sentencia judicial firme". - En el caso de la STS de 13 mayo 2014 (casación 2417/2013; Ar. 3644) se partía de la anulación de una licencia en cuya virtud se había construido un edificio. El Ayuntamiento aprobó después un plan parcial y alegó que con éste devenía imposible la ejecución de 
de que ello conste ya en la motivación del acto $^{(50)}$. Y el tribunal, que puede presumir la concurrencia de esa finalidad espuria, no puede simplemente negarla con argumentos genéricos ${ }^{(51)}$. No obstante, escapan de esta presunción las actuaciones anteriores a la sentencia supuestamente burlada, casos para los que el TS español exige una prueba cumplida de la finalidad elusiva(52).

Merced a esa presunción iuris tantum se suaviza el requisito subjetivo ${ }^{(53)}$. Pero nunca se elimina: su concurrencia es necesaria y su falta impide declarar la nulidad del artículo 103.4 LJCA $^{(54)}$. Más todavía: su presencia es lo que distingue los supuestos de nulidad del artículo 103.4 LJCA de aquellos otros en los que una actuación administrativa posterior podrá ser causa lícita de imposibilidad legal de ejecución. Téngase en cuenta que, conforme al artículo 105.2 LJCA, puede haber causas de imposibilidad

la sentencia (demolición). Pero el TS afirmó que "(...) no se ha demostrado que la modificación del Plan Parcial que el Ayuntamiento opone a la ejecución de la sentencia tuviera otra finalidad que la de eludir su cumplimiento. En este sentido conviene señalar que (...) no es al recurrente y sí, en todo caso, a la Administración a quien corresponde acreditar que la modificación del planeamiento no tiene por finalidad sortear la ejecución de la sentencia. Y en el presente caso, no ha justificado que las determinaciones que integran el contenido de la modificación tengan un objetivo distinto del señalado". Con ello entendió que el nuevo plan parcial "tuvo por finalidad eludir el cumplimiento de la sentencia firme dictada (...) y en consecuencia debe ser anulado, de conformidad con lo dispuesto en el artículo 103.4 de la Ley de esta Jurisdicción".

- Según la STS de 19 de febrero de 2013 (casación 5525/2010; Ar. 3195), si un nuevo plan va a impedir la ejecución de una sentencia es necesaria una especial "motivación esmerada y rigurosa" para enervar la sospecha de su finalidad espuria.

- La STS de 28 de septiembre de 2009 (casación 2573/2005; Ar. 7345) señala que, ante la previa anulación de una licencia, "para introducir una nueva ordenación urbanística cuya aprobación comporta la inefectividad de esos pronunciamientos jurisdiccionales o hará inviable su cumplimiento, la Administración debe necesariamente realizar un especial esfuerzo para justificar el cambio de ordenación llamado a tener tan grave consecuencia, y, en fin, para disipar cualquier sospecha de que el planeamiento se altera con la intención de impedir el cumplimiento de la sentencia".

Igualmente, SSTS de 8 de noviembre de 2012 (casación 4561/2011; Ar. 10 656); de 10 de mayo de 2007 (casación 3786/2004, Ar. 8062); de 12 de julio de 2004 (casación 1644/2002; Ar. 4242); de 4 de mayo de 2004 (Ar. 5298); de 10 de diciembre de 2003 (casación 2550/2001, Ar. 107 de 2004).

A veces, sin embargo, el TS se muestra algo más exigente con la prueba de la finalidad fraudulenta o, al menos, hace declaraciones que tratan de conciliar esta jurisprudencia con la general sobre la prueba de la desviación de poder. E incluso ha aceptado ciertos "indicios de inexistencia de desviación de poder". Así, SSTS de 23 de diciembre de 2010 (casación 2970/2006; Ar. 1033 de 2011) y de 18 de diciembre de 2014 (casación 2847/2012; Ar. 6823).

(50) Por ejemplo, STS de 17 de junio de 2009 (casación 1135/2008; Ar. 2009).

(51) Así se infiere de la STS 1955/2016, de 21 de julio (casación 3916/2015; Ar. 3916) que anuló los autos del tribunal de instancia que dieron por bueno un nuevo Estudio de Detalle aprobado en sustitución del anteriormente anulado porque no explicaron suficientemente que no tuviera finalidad elusiva de modo que le remitió las actuaciones "para que examine y decida con libertad de criterio" si el nuevo plan es o no ajustado a Derecho y, en concreto, si se aprobó con la finalidad de eludir la sentencia. Es, además, una apreciación que corresponde al juzgado o tribunal que conozca en primera instancia y cuya valoración sólo muy limitadamente puede cambiarse en apelación o casación. Dice a este respecto la STS 113/2019, de 4 de febrero (casación 3965/2017; Ar. 354): “(...) en principio la apreciación de las circunstancias de las que se desprende la intención u objetivo de eludir el cumplimiento de la sentencia corresponde al órgano de primera instancia competente para la ejecución del fallo, valoración que no puede sustituirse o revisarse si no se justifica la arbitrariedad o irracionalidad de la misma (...)".

(52) Afirma la STS 1997/2016, de 6 de septiembre (casación 3365/2014; Ar. 5776) que, en los supuestos de actuaciones administrativas anteriores a la sentencia, pero producidas vaticinando el resultado adverso "se impone un grado de demostración de la finalidad elusiva más intenso que el habitual". En la misma dirección SSTS de 12 de marzo de 2015 (casación 1881/2014, Ar. 3626) y de 18 de diciembre de 2014 (casación 2847/2012; Ar. 6823). Asimismo, la STS de 19 de junio de 2013 (casación 2713/2012) dice que "en este supuesto de actos anteriores para evitar la ejecución esperada, la aplicación del artículo 103.4 LJCA exige un grado de demostración de la finalidad elusiva más intenso que cuando se trata de actos dictados con posterioridad al fallo". Y la STS de 23 de diciembre de 2010 (casación 2970/2006; Ar. 1033 de 2011) declaró que "es indicio de inexistencia de desviación de poder si la sentencia se dicta con posterioridad a la aprobación del nuevo planeamiento". Por todo ello dijo ya la STS de 28 de marzo de 2006 (casación 8466/2002; Ar. 3138) que "resulta muy difícil imputar tal vicio a la Orden aprobatoria de la Revisión del Plan General de Ordenación Urbana cuando aún faltaban dos meses para que se dictara la sentencia".

(53) Incluso hay sentencias que casi no aluden a él. Por ejemplo, STS de 30 de abril de 2008 (casación 7159/2004, Ar. 5375) que considera incursa en la nulidad del artículo 103.4 la convalidación de una expropiación sin referencia alguna al ánimo fraudulento. Tampoco se insiste en ese fin en la STS de 15 de diciembre de 2010 (casación 3699/2008, Ar. 3350) para declarar la nulidad de un plan especial dictado en sustitución de un estudio de detalle anulado judicialmente.

(54) Que este elemento subjetivo es siempre necesario se ve notoriamente en la STS de 21 de junio de 2005 (casación 4936/2002; Ar. 8968): en ese caso se reconoció que se había contradicho la sentencia puesto que se habían calificado como urbanos suelos que según la sentencia anulatoria de un plan no tenían los servicios para ello; y, aun así, en ejecución de dicha sentencia, no anuló conforme al artículo 103.4 LJCA porque no apreció que los actos en cuestión "se dictaran, precisamente, con la finalidad de eludir el cumplimiento de la sentencia". 
legal de ejecutar las sentencias que, en su caso, declarará el Juzgado o Tribunal, aunque al mismo tiempo deberá adoptar las medidas que aseguren la mayor efectividad de la sentencia (sobre todo, mediante indemnizaciones). Entre esas causas legales de imposibilidad de ejecución están los nuevos reglamentos o las modificaciones de los existentes. Pues bien, lo que afirmamos es que, según esas nuevas disposiciones reglamentarias se juzguen dictadas con sus fines normales o con el fin espurio de eludir la sentencia, serán válidas y causas de inejecución de la sentencia del artículo 105.2 LJCA o, por el contrario, nulas conforme al artículo 103.4 LJCA. Dicho de otra forma, y por paradójico que resulte, un nuevo reglamento será causa de inejecución de sentencia a condición de que no sea eso lo que deliberadamente busque ${ }^{(55)}$. Incluso a falta en la peruana LPCA de un artículo similar al artículo 105.2 LJCA, la solución, por lógica, debe ser la misma.

\section{3. ¿Qué sucede si falta alguno de los requisitos?}

Tal vez estos elementos objetivo y subjetivo podrían haberse establecido como alternativos de forma que bastase uno u otro para incurrir en nulidad(56). Pero claramente el artículo 48 LPCA, al igual que el artículo 103.4 LJCA, ha optado por configurarlos como acumulativos. A ello, como se ha visto, se atiene la jurisprudencia española. Por tanto, si falta alguno de los dos no cabrá apreciar esta causa de nulidad ${ }^{(57)}$. Cosa distinta es que eventualmente sí que pueda bastar alguno de esos dos requisitos para que la actuación administrativa tenga algún otro vicio invalidante distinto del específico de los artículos 48 LPCA y 103.4 LJCA. Así podría decirse que, como el requisito subjetivo se asimila a una desviación de poder y como ésta por sí sola es determinante de invalidez (artículo 70.2 LJCA), bastaría para conseguir su anulación. De hecho, así lo ha insinuado el TS ${ }^{(58)}$. Sobre todo se ha sostenido que el mero elemento objetivo de la contradicción con la sentencia debería ser bastante para poder anular la actuación administrativa ${ }^{(59)}$. Y, en efecto, no cabe descartar que, al margen de los preceptos analizados, la contradicción con la sentencia sin ánimo elusivo sea suficiente en algunas hipótesis para detectar otro vicio invalidante, máxime si se entiende vulnerado el derecho fundamental a la tutela judicial efectiva en su vertiente de derecho a la ejecución de las sentencias. Pero, aunque así se acepte habrá de aplicarse con cautelas. De una parte, tal vicio invalidante no cabría argüirlo y estimarlo en el cauce de ejecución de sentencias que se contrae a la causa de nulidad de los artículos 48 LPCA y 103.4 LJCA con sus dos requisitos. De otra parte, deberá diferenciarse la actuación administrativa que puramente contraría a la sentencia de aquélla

(55) Así, Galán Galán (2006, p. 146), dice que si falta el requisito subjetivo de la finalidad elusiva "estaremos ante un supuesto de imposibilidad de ejecución (...) Este elemento subjetivo (...) se convierte, de este modo, en el criterio determinante de la aplicación del artículo 103.4 ó del artículo 105.2 LJCA”. En igual dirección Chinchilla Peinado (2008, p. 74), deduce de esa exigencia subjetiva del artículo 103.4 LJCA, que si falta tal finalidad, el acto o disposición sería legal: "(...) sensu contrario supone el reconocimiento de la legalidad de aquellos otros actos o disposiciones que se hayan dictado o adoptado sin que concurra dicha finalidad" que podrán determinar la "imposibilidad de ejecución de la sentencia en los términos del artículo 105.2 LJCA". Y Font i Llovet (2003, p. 825) dice: "(...) no debe olvidarse que sólo es esa finalidad elusiva (...) lo que se considera ilegítimo en grado de nulidad, puesto que no debe pensarse que se produce un bloqueo o congelación de una determinada ordenación por el hecho de haber sido objeto de un pronunciamiento judicial. La Administración no pierde sus potestades, lo que no puede es ejercerlas para incumplir una sentencia".

(56) O seguramente habría sido muy correcto haber añadido el requisito subjetivo únicamente para los casos en los que la Administración altera el marco normativo en que se desenvolvió la sentencia para así distinguir, sólo en tal género de supuestos, los afectados por el artículo 103.4 y los que puedan entrar en el artículo 105.2 LJCA como causas lícitas de imposibilidad de ejecución de sentencias. En los demás, bastaría el requisito objetivo. Es lo que apunta Huergo Lora (2001, p. 297-298).

(57) En contra, Huergo Lora (2001, p. 299) llega a decir que, "pese al tenor literal del artículo 103.4 LJCA", son nulos de pleno derechos conforme a ese precepto todos los actos contrarios a la sentencia "sin necesidad de indagar su intención". También Castillo Blanco, F. (2018). La ejecución propia e impropia de sentencias en el ámbito contencioso-administrativo, RAAP, 100, p. 103: propugna que se prescinda de la exigencia de la finalidad y afirma que, aunque la redacción legal "parece involucrar un elemento volitivo (...) dirigido a eludir el cumplimiento del fallo (...), es el contenido material del acto el factor determinante de la infracción de nulidad, independientemente de que concurriese o no tal finalidad".

(58) Se ve en la STS de 19 de febrero de 2013 (casación 5525/2010; Ar. 3195): aplica el artículo 104.3 LJCA para anular un plan dictado para evitar la ejecución de una sentencia; pero añade: “... aun en el supuesto dialéctico de que se entendiera no estrictamente aplicable el artículo 103.4 LJCA (...) siempre cabría apreciar esa desviación de poder mediante la cláusula general del artículo 70 de la misma Ley (...)".

(59) Baño León (2016, p. 97-98 y 100), tras censurar la exigencia del animus, concluye que cualquier acto o reglamento contrario a la cosa juzgada es nulo de pleno derecho de acuerdo con el artículo 47.1.a) LPAC, esto es, el que prevé la nulidad para los actos que vulneren derechos fundamentales: sería contrario al derecho fundamental a la tutela judicial efectiva con independencia de que se haya dictado con la finalidad de incumplir la sentencia y del artículo 103.4 LJCA. Igualmente dijo Xiol Ríos (2016, p. 722), que, como los actos contrarios al fallo vulneran el derecho a la ejecución de las sentencias y como éste está comprendido en el derecho a la tutela judicial efectiva del artículo $24 \mathrm{CE}$, son nulos de pleno derecho. 
otra que deba considerarse lícita, aunque imposibilite la ejecución de la sentencia y que cabrá invocar con éxito en el incidente del artículo 105.2 LJCA. Y a decir verdad tal diferenciación, si se prescinde del elemento subjetivo de la finalidad de eludir la sentencia, es sutil y extremadamente difícil ${ }^{(60)}$.

\section{Límites generales a esta causal de nulidad y a su enjuiciamiento en ejecución de sentencias}

Aun reconociendo las muchas virtualidades del artículo 48 LPCA y de la posible apreciación de su causa de nulidad en ejecución de las sentencias, también existe el riesgo de su aplicación excesivamente laxa. De hecho, de algunas sentencias españolas puede desprenderse que el riesgo no es meramente hipotético. Frente a ello son oportunas algunas observaciones que pueden ser valiosas para que no se caiga en esos excesos.

En primer lugar, hay que recordar que tan importante como la plena ejecución de las sentencias es la intangibilidad del fallo que prohíbe, entre otras cosas, acordar en ejecución lo que no se desprende inequívocamente de la sentencia ${ }^{(61)}$.

La segunda observación pertinente es que inflar la ejecución de las sentencias no es siempre un avance del Estado de Derecho, sino que puede constituir un riesgo ${ }^{(62)}$, incluso para el derecho a la tutela judicial efectiva de los otros sujetos que, sin ser partes ni haberse podido defender, pueden ver comprometidos sus intereses en ejecuciones judiciales desbocadas que pretendan resolver allí todo lo que de alguna forma tenga remota relación con lo fallado(63).
Por último, pero no con menos importancia, hay que aclarar que no se pueden llevar a la ejecución de sentencias (por ejemplo, a las que anulen un acto $o$ un reglamento) todas las pretensiones que se basen en su cosa juzgada material: precisamente se consagra el efecto prejudicial de la cosa juzgada en todo género de procesos porque se parte de que muchas pretensiones que encuentran apoyo en una sentencia previa firme deben ser objeto de otros procesos, no de la ejecución de la primera sentencia; no se tratará de ejecutar lo decidido en la sentencia sino de decidir otra cosa aunque en el silogismo judicial juegue como premisa incontrovertible la sentencia anterior ${ }^{(64)}$.

Como colofón de todo esto, conviene la cita de la STS 1774/2016 de 14 julio (casación núm. 3620/2015. Ar. 3799) que limita el artículo 103.4 LJCA así:

“(...) resulta necesario que los actos, cuya nulidad se pretende, sean actos conectados de forma clara con la actividad de ejecución, por relacionarse de forma directa con el contenido del fallo de la sentencia"(65).

Esta misma idea, sostengo, debe orientar la aplicación del artículo 48 LPCA de modo que sólo se lleven a la ejecución de las sentencias las nulidades de actos

(60) Recuérdese que, como hemos destacado en nota anterior, Galán Galán (2006, p. 146) y Chinchilla (2008, p. 74) ponen precisamente la frontera entre el artículo 103.4 y artículo 105.2 LJCA en la existencia o no del requisito subjetivo, o sea, en la finalidad elusiva de la sentencia.

(61) Como explica, por todos, Ezquerra Huerva (2014, p. 939), cuando se habla de la "intangibilidad del fallo" hay que afirmar que ese principio "opera de modo bidireccional, toda vez que protege por igual a ambas partes procesales -y a cualesquiera afectados...frente a una ejecución apartada de lo estrictamente decidido en la sentencia". De modo que la intangibilidad del fallo no permite dejarlo corto en perjuicio de una parte; pero tampoco sacar de él más de la cuenta en perjuicio de la otra. Y esto último es lo que parece haber sucedido en muchos casos. Téngase en cuenta, además, que según el TC (por ejemplo, sentencia 219/1994) también el condenado/ejecutado, incluyendo a la Administración, tiene un derecho fundamental a que en la ejecución no vaya más allá de lo que exige el fallo.

(62) Baño León (2016, p. 99), ha llegado a decir que "la exacerbación del derecho a la tutela judicial efectiva, en su vertiente de derecho a la ejecución de las sentencias, ha ampliado de manera notable los poderes de ejecución del juez hasta el punto en que es difícil saber si no se está afectando al principio de división de poderes...".

(63) Dicen, por ejemplo, las SSTS 475 y 476/2018, de 21 de marzo, que quedan fuera de la ejecución las cuestiones no decididas por el fallo "porque podría ser menoscabado el derecho a la tutela judicial de terceros al margen del procedimiento declarativo correspondiente, del que no se les puede privar".

(64) Por eso no puede compartirse la tesis de Huergo Lora (2001, p. 299-302): “(...) el conjunto de cuestiones a las que se extiende (la) autoridad de cosa juzgada pueden ser ventiladas en el incidente de ejecución, sin necesidad de iniciar un nuevo proceso declarativo (...)". Y después: "(...) lo que nunca es necesario es que el recurrente "victorioso" acuda a estos procesos (declarativos) ulteriores para hacer valer los efectos de la cosa juzgada". No es así: el efecto de cosa juzgada y los efectos ejecutivos son y permanecen distintos; aquél tiene mayor ámbito que éste. Y no es aceptable que cualquier conflicto en el que la cosa juzgada juegue con su simple efecto prejudicial se lleve a la ejecución de la sentencia. Ni siquiera sumando la cosa juzgada a los efectos materiales de las sentencias anulatorias ello es admisible. Los peligros de esa tesis suben de grado si se trata de sentencias anulatorias de reglamentos, supuesto en el que llevaría a convertir las ejecuciones en causas generales inmanejables.

(65) Por supuesto que esto no es completamente nuevo ni ajeno a la jurisprudencia del TC. Por ejemplo, decía ya la STC 219/1994: “(...) con ocasión de los incidentes de ejecución no es posible resolver cuestiones que no hayan sido abordadas ni decididas en el 
y reglamentos conectados de forma clara y directa con lo decidido en la sentencia previa de que en cada caso se trate.

\section{Conclusiones}

Tras todo lo expuesto pueden formularse estas conclusiones para el Derecho peruano a la vista del artículo 48 del Texto Único Ordenado de la Ley que regula el Proceso ContenciosoAdministrativo:

- La causa de nulidad enunciada en ese precepto puede concurrir ante la vulneración de sentencias firmes de condena, pero también de las meramente declarativas o constitutivas.

- Esa causa de nulidad sólo se da con dos requisitos: uno objetivo, que es la contradicción con el fallo de la sentencia, aunque entendido y acotado tal fallo en función de la ratio decidendi de la sentencia; otro subjetivo de modo que sólo se dará esta nulidad cuando el acto en cuestión se haya dictado precisamente con la finalidad de eludirlo.

- Aunque no se consagra expresamente en la LPCA, la nulidad de su artículo 48 puede hacerse valer en todo caso en ejecución de la sentencia vulnerada sin tener que tramitar un nuevo proceso contencioso-administrativo autónomo y declarativo. Además, puede hacerse sin recursos administrativos previos que, si acaso, serán potestativos.

- No obstante lo anterior, también es posible alegar con éxito esta causa de nulidad, junto con otros vicios, en un proceso contencioso-administrativo autónomo y declarativo pero sólo si se trata de impugnar actos dictados en ejercicio de las potestades ordinarias de la Administración, no si son actos dictados justamente para el cumplimiento de la sentencia.

\section{Referencias Bibliográficas}

Agoués Mendizábal, C. (2017). La modulación de los efectos de la invalidez de los reglamentos. En El alcance de la invalidez de la actuación administrativa: Actas del XII Congreso de la Asociación Española de Profesores de Derecho Administrativo. Madrid: Instituto Nacional de Administración Pública (INAP).

Baño León, J. M. (1998). Artículo 103.4 y 5. Revista Española de Derecho Administrativo, 100, p. 719-726.
(2012). La retroacción de actuaciones ¿denegación de justicia o garantía del justiciable? En E. García Enterría y R. Alonso García (coord.), Administración y justicia. Un análisis jurisprudencial. Liber amicorum Tomás-Ramón Fernández (Vol. 1). Madrid: Civitas.

(2016). La eficacia de las sentencias contra la Administración o la claudicación del Estado de Derecho. Revista Española de Derecho Administrativo, 177, p. 85-102

Bueno Armijo, A. (2016). La revisión de oficio. En H. Gosálbez Pequeño (direct.), La nueva Ley del Procedimiento Administrativo Común (p. 371-450). Madrid: Wolters Kluwer.

Calvo Rojas, E. (2012). Los planes urbanísticos como disposiciones de carácter general. Problemas que suscita la declaración de nulidad de los instrumentos de planeamiento. Suspensión cautelar de la efectividad de los planes impugnados en vía jurisdiccional”. En E. García Enterría. y R. Alonso García (coord.), Administración y justicia. Un análisis jurisprudencial: liber amicorum Tomás-Ramón Fernández (Vol. 1, p. 821-840). Madrid: Civitas.

Cano Campos, T. (2004). La invalidez sobrevenida de los actos administrativos. Madrid: Civitas

Castillo Blanco, F. (2018). La ejecución propia e impropia de sentencias en el ámbito contenciosoadministrativo, Revista Andaluza de Administración Pública, 100, p. 87-129.

Chinchilla Peinado, J. A. (2008). La ejecución aparente del fallo de las sentencias contenciosoadministrativas en el ámbito urbanístico. Un balance tras 10 años de vigencia de la Ley 29/1998, Revista de Derecho Urbanístico y Medioambiente, 245, p. 65-100.

Clavero Arévalo, M. (2003). Actuaciones administrativas contrarias a los pronunciamientos de las sentencias. En M. Montoro Chiner (coord.), La justicia administrativa. Libro homenaje al Prof. Dr. D. Rafael Entrena Cuesta. Barcelona: Atelier.

Ezquerra Huerva, A. (2014). La ejecución de sentencias. En A. Ezquerra Huerva y J. Oliván del Cacho. (direct.), Estudio de la Ley de la Jurisdicción Contencioso-Administrativa (p. 975-976). Valencia: Tirant lo Blanch.

Fernández Hernando, J. (1961). El incumplimiento de la sentencia administrativa, sus formas y su

fallo o con las que éste no guarde una inmediata o directa relación de causalidad, pues, de otro modo, no sólo se vulnerarían las normas legales que regulan la ejecución sino que podría resultar menoscabado, asimismo, el derecho a la tutela judicial efectiva de las otras partes procesales o de terceros [SSTC 125/1987, fundamentos jurídicos 4 y 5 ; 167/1987, fundamento jurídico 2; 215/1988, fundamento jurídico 3, 148/1989, fundamento jurídico 4]". Nótese que no sólo exige, como mínimo, una inmediata o directa relación con lo fallado, sino que, en línea con lo que hemos dicho más arriba, afirma que lo contrario, lejos de favorecer la tutela judicial efectiva, vulneraría la de otras partes o la de terceros. También la STC 231/2015 orienta en la misma dirección al hablar de consecuencias del fallo que deriven "necesariamente de él de modo directo, inmediato e inequívoco" y excluir las que no reúnan esos requisitos del derecho a la ejecución de sentencias. 
Nulidad de actos administrativos contrarios a las sentencias en el Texto Único Ordenado de la Ley peruana del Proceso Contencioso-Administrativo

Nullity of administrative acts contrary to the judgments in the "Texto Único Ordenado" of the ContentiousAdministrative Process Law

tratamiento jurisprudencial. En Libro homenaje al profesor Jordana de Pozas (Vol. I, Tomo III, p. 248-253). Madrid: Instituto de Estudios Políticos.

Fernández Rodríguez, T. R. (1974). Algunas reflexiones sobre las formas indirectas de incumplimiento por la Administración de las sentencias de los tribunales de la jurisdicción contencioso-administrativa, Revista de Administración Pública, 73, p. 151-178.

(2011). El artículo 130.4 LJCA no les gusta a los jueces. En Sánchez Blanco, A., Domínguez Berrueta de Juan, M. A., y Rivero Ysern, J. L. (coord.), El nuevo Derecho Administrativo. Libro homenaje al Profesor Dr. Enrique Rivero Ysern (p. 139-146). Salamanca: Ratio Legis y Universidad de Salamanca.

Fernández Torres, J. R. (2018). La ejecución de sentencias sigue siendo un auténtico quebradero de cabeza veinte años después de la aprobación de la LJCA. RAAP, 100, p. 175.

Font i Llovent, T. (1985). La ejecución de las sentencias contencioso-administrativas. Aspectos constitucionales. Madrid: Civitas.

(1993). Medidas para hacer efectiva la ejecución de las sentencias. En L. MartínRetortillo Baquer (coord.), La protección jurídica del ciudadano. Estudios en homenaje al Profesor Jesús González Pérez. Madrid: Civitas.

(2003). Justicia administrativa y ejecución de sentencias. En Montoro Chiner, M. J. (coord.), La justicia administrativa. Libro homenaje al Prof. Dr. D. Rafael Entrena Cuesta (p. 822-826). Barcelona: Atelier.

Galán Galán, A. (2006). Los poderes del juez en la ejecución de las sentencias: reacción frente a actos de la Administración o del legislador que tengan como fin eludir su cumplimiento. En A. Sánchez Lamelas (coord.), La ejecución de las sentencias contencioso-administrativas (p. 133174). Madrid: Aranzadi Thomson Reuters.

García Luengo, J. (2002). Los supuestos de nulidad de pleno derecho establecidos al margen de la Ley de Procedimiento Común, Revista de Administración Pública, 159, p. 137-172.

Gimeno Sendra, V. (1999). Comentarios a la nueva Ley de la Jurisdicción Contencioso-Administrativa. Madrid: Centro de Estudios Ramón Areces.

Gómez-Ferrer Rincón, R. (2008). La imposibilidad de ejecución de sentencias en el proceso contenciosoadministrativo. Madrid: Civitas, Cizur Menor.
González Pérez, J. (2016). Comentarios a la Ley de la Ley de la Jurisdicción Contencioso-Administrativa (8va ed.). Madrid: Civitas, Cizzur Menor.

Huergo Lora, A. (2001). La permanencia de un viejo problema: la reiteración de los actos administrativos anulados como forma de incumplimiento indirecto de las sentencias, con especial referencia a los efectos de los recursos de casación en interés de Ley, Revista de Administración Pública, 156, p. 283-306.

Huerta Garicano, I. (2000). La ejecución de sentencias en la Ley 29/1998, de la Jurisdicción Contencioso-Administrativa. Cuadernos de Derecho Judicial, 2, p. 97-122.

Morillo-Velarde Pérez, J. I. (1999). La ejecución de sentencias en el proceso contencioso administrativo. Revista del Poder Judicial, 55, p. 325-350.

Ortega Álvarez, L. (2001). La ejecución de sentencias. En Leguina Villa, J. y Sánchez Morón, M. (direct.), Comentario a la Ley de la Jurisdicción Contencioso-Administrativa (2da ed.). Valladolid: Lex Nova.

(1999). La ejecución de sentencias, Justicia Administrativa: Revista de Derecho Administrativo, número extraordinario 1, p. 153164.

Rebollo Puig, M. (1998). Artículos 72 y 73, Revista Española de Derecho Administrativo, 100, p. 517-537.

(2018). Efectos de las sentencias anulatorias de reglamentos. En especial, su retroactividad, RAAP, 100, p. 469-526.

Ruiz Bursón, F. J. (2013), Las innovaciones en el planeamiento urbanístico como causa de imposibilidad legal para la ejecución de sentencias, Revista General de Derecho Administrativo, 33.

Santamaría Pastor, J. A. (2010). La Ley Reguladora de la Jurisdicción Contencioso-Administrativa. Madrid: lustel.

(2014). Muerte y transfiguración de la desviación de poder: sobre las sentencias anulatorias de los planes, RAP, 195, p. 197 y 215.

Suay Rincón, J. (2014). La caracterización jurídica de la potestad de revisión de oficio. En J. Soriano-García (direct.), Por el Derecho y la libertad. Libro homenaje al Profesor Juan Alfonso Santamaría Pastor (Tomo II). Madrid: lustel.

(2018). La "afectación" de la anulación de los Planes de Urbanismo a sus actos de ejecución: la perspectiva de la Ley Jurisdiccional, Revista de Derecho Urbanístico y Medio Ambiente, 324, p. 19-64.

Tolosa Tribiño, C. (2006). El incidente de ejecución de sentencias: aspectos procesales. En Sánchez Lamelas, A. (coord.), La ejecución de sentencias contencioso-administrativas (p. 178-179). Madrid: Aranzadi Thomson Reuters.

Tornos Mas, J. (1998). Artículo 103.1, 2 y 3, Revista Española de Derecho Administrativo, 100, p. 715-719.

Xiol Ríos, J. A. (2016). Artículo 103. En E. Espín Templado (coord.), Comentarios a la Ley Reguladora de la Jurisdicción ContenciosoAdministrativa. Valencia: Tirant lo Blanch. 